\title{
Advances in $\mathrm{Ca}^{2+}$ modulation of gastrointestinal anion secretion and its dysregulation in digestive disorders (Review)
}

\author{
WEIXI SHAN $^{1 *}$, YANXIA HU $^{1 *}$, JIANHONG DING $^{1}$, XIAOXU YANG $^{1}$, JUN LOU $^{1}$, \\ QIAN DU ${ }^{1}$, QIUSHI LIAO ${ }^{1}$, LIHONG LUO ${ }^{2}$, JINGYU XU ${ }^{1}$ and RUI XIE ${ }^{1}$ \\ ${ }^{1}$ Department of Gastroenterology, The Affiliated Hospital of Zunyi Medical University, Zunyi, Guizhou 563003; \\ ${ }^{2}$ Department of Oncology and Geriatrics, Traditional Chinese Medicine Hospital of Chishui City, Guizhou 564700, P.R. China
}

Received January 15, 2020; Accepted May 22, 2020

DOI: $10.3892 /$ etm.2020.9136

\begin{abstract}
Intracellular calcium $\left(\mathrm{Ca}^{2+}\right)$ is a critical cell signaling component in gastrointestinal (GI) physiology. Cytosolic calcium $\left(\left[\mathrm{Ca}^{2+}\right]_{\text {cyt }}\right)$, as a secondary messenger, controls GI epithelial fluid and ion transport, mucus and neuropeptide secretion, as well as synaptic transmission and motility. The key roles of $\mathrm{Ca}^{2+}$ signaling in other types of secretory cell (including those in the airways and salivary glands) are well known. However, its action in GI epithelial secretion and the underlying molecular mechanisms have remained to be fully elucidated. The present review focused on the role of $\left[\mathrm{Ca}^{2+}\right]_{\text {cyt }}$ in GI epithelial anion secretion. $\mathrm{Ca}^{2+}$ signaling regulates the activities of ion channels and transporters involved in GI epithelial ion and fluid transport, including $\mathrm{Cl}^{-}$channels, $\mathrm{Ca}^{2+}$-activated $\mathrm{K}^{+}$channels, cystic fibrosis (CF) transmembrane conductance regulator and anion $/ \mathrm{HCO}_{3}{ }^{-}$exchangers. Previous studies by the current researchers have focused on this field over several years, providing solid evidence that $\mathrm{Ca}^{2+}$ signaling has an important role in the regulation of GI epithelial anion secretion and uncovering underlying molecular mechanisms. The present review is largely based on previous studies by the current researchers and provides an overview of the currently known molecular mechanisms of GI epithelial anion secretion with an emphasis on $\mathrm{Ca}^{2+}$-mediated ion secretion and its dysregulation in GI disorders. In addition, previous studies by the current researchers demonstrated that different regulatory mechanisms are in place for $\mathrm{GI}$ epithelial $\mathrm{HCO}_{3}$ and $\mathrm{Cl}^{-}$secretion. An increased understanding of the roles of $\mathrm{Ca}^{2+}$ signaling and its targets in GI anion secretion may lead
\end{abstract}

Correspondence to: Professor Jingyu Xu or Professor Rui Xie, Department of Gastroenterology, The Affiliated Hospital of Zunyi Medical University, 149 Dalian Road, Zunyi, Guizhou 563003, P.R. China

E-mail: xujingyu_gzzy@126.com

E-mail: xr19841029@aliyun.com

${ }^{*}$ Contributed equally

Key words: calcium, intestinal, ion channel, secretion to the development of novel strategies to inhibit GI diseases, including the enhancement of fluid secretion in $\mathrm{CF}$ and protection of the GI mucosa in ulcer diseases.

\section{Contents}

1. Introduction

2. General aspects of GI epithelial anion secretion

3. $\mathrm{Ca}^{2+}$ modulation of GI epithelial anion secretion

4. Associated GI diseases

5. Conclusion

\section{Introduction}

It is well known that $\left[\mathrm{Ca}^{2+}\right]_{\mathrm{cyt}}$ has an essential role in numerous important mammalian cell functions, including neurotransmitter release, gene regulation, muscle contraction, cell proliferation, differentiation and apoptosis (1). Since the function of $\left[\mathrm{Ca}^{2+}\right]_{\mathrm{cyt}}$ as the cell's secondary messenger is based on the presence of a concentration gradient between $\left[\mathrm{Ca}^{2+}\right]_{\mathrm{cyt}}$ and external $\mathrm{Ca}^{2+}\left(\left[\mathrm{Ca}^{2+}\right]_{\mathrm{ext}}\right)(2)$, normal $\left[\mathrm{Ca}^{2+}\right]_{\mathrm{cyt}}$ homeostasis is important. Under normal physiological conditions, the concentration of $\left[\mathrm{Ca}^{2+}\right]_{\text {cyt }}$ is $<100 \mathrm{nM}$, which is $\sim 10,000$ times lower than $\left[\mathrm{Ca}^{2+}\right]_{\mathrm{ext}}(>1 \mathrm{mM})(3,4)$. Furthermore, the membrane potential of $\sim-60 \mathrm{mV}$ adds to the large electrochemical gradient and this huge concentration gradient favors the entry of $\mathrm{Ca}^{2+}$ into cells (5). Therefore, when cells are activated, $\mathrm{Ca}^{2+}$ is transported down this electrochemical gradient into the cells through the specific transmembrane $\mathrm{Ca}^{2+}$ channels, leading to increases in the $\left[\mathrm{Ca}^{2+}\right]_{\text {cyt }}(5)$.

To restore the resting levels of $\left[\mathrm{Ca}^{2+}\right]_{\mathrm{cyt}}, \mathrm{Ca}^{2+}$ is transported back to the extracellular space or stored in intracellular $\mathrm{Ca}^{2+}$ pools by $\mathrm{Ca}^{2+}$ pumps and transporters $(6,7)$. Furthermore, $\left[\mathrm{Ca}^{2+}\right]_{\text {cyt }}$ exhibits differences functions in different type of cells (8). These are key factors that determine different specific $\mathrm{Ca}^{2+}$-dependent cellular responses affected by complex, spatiotemporal variations in $\left[\mathrm{Ca}^{2+}\right]_{\text {cyt }}$ (Fig. 1). A major determinant of these variations are different functionally distinct membrane calcium channels and exchangers, such as the receptor-operated calcium channels, voltage-gated channels, $\mathrm{Na}^{+} / \mathrm{Ca}^{2+}$ exchangers (NCX) and calcium pumps (9). In addition, the intracellular stores are an important determinant 
for $\mathrm{Ca}^{2+}$ release (10). To date, the ryanodine receptor (RyR) and inositol triphosphate receptor $\left(\mathrm{IP}_{3} \mathrm{R}\right)$ channels on the endoplasmic reticulum (ER), have been identified, which lead to $\mathrm{Ca}^{2+}$-induced $\mathrm{Ca}^{2+}$ release (CICR) or release of $\mathrm{IP}_{3}$, respectively, to mediate the release of $\mathrm{Ca}^{2+}$ from intracellular stores and increasing the $\left[\mathrm{Ca}^{2+}\right]_{\mathrm{cyt}}(11)$.

In the digestive system, $\left[\mathrm{Ca}^{2+}\right]_{\text {cyt }}$ also has critical roles in the regulation of digestive functions $(12,13)$. This includes GI motility and ion transport, food digestion and nutrient absorption (14). In the epithelial cells of the GI tract, ion secretion and absorption of electrolytes and fluid are two essential functions and ion transport is also a critical physiological process in the human GI tract (15). GI epithelium secretes anions $\left(\mathrm{Cl}^{-}\right.$ and $\mathrm{HCO}_{3}{ }^{-}$), providing the driving force for fluid transport to maintain fluid homeostasis in the human body (16). GI epithelial anion secretion is controlled by several neuro-humoral factors, including prostaglandin E2 (PGE2), acetylcholine (ACh) and 5-hydroxytryptamine (5-HT) (17). These factors mediate epithelial anion secretion mainly through $\mathrm{Ca} 2+$, cyclic adenosine monophosphate (cAMP) and cyclic guanosine monophosphate (cGMP) signaling pathways (17).

The physiological roles and molecular mechanisms of cAMP- and cGMP-dependent regulation of GI epithelial anion secretion have been extensively defined (18). Since certain adenylyl cyclase subtypes are $\mathrm{Ca}^{2+}$-dependent and multiple interactions between $\mathrm{Ca}^{2+}$ and cAMP signaling pathways exist in mammalian cells, it was previously thought that $\mathrm{Ca}^{2+}$ may mediate epithelial anion secretion indirectly through cAMP signaling (19).

However, various lines of evidence indicate that $\mathrm{Ca}^{2+}$ signaling is able to mediate epithelial anion secretion in a cAMP-independent manner $(19,20)$. Although the critical role of $\mathrm{Ca}^{2+}$-dependent regulation has been verified, the underlying regulatory mechanisms remain to be fully elucidated. The current researchers have been investigating the $\mathrm{Ca}^{2+}$-mediated regulation of anion secretion by GI epithelium and provided solid evidence for a regulatory role of $\mathrm{Ca}^{2+}$ signaling in a cAMP-independent manner, as well as the underlying molecular mechanisms (19).

While the critical role of $\mathrm{Ca}^{2+}$ signaling in other types of secretory cell (such as those of the airways and salivary gland) is well known (21), the roles of $\mathrm{Ca}^{2+}$ signaling in GI epithelial secretion and its molecular mechanisms have remained to be fully elucidated. Further research is required to molecularly identify the $\mathrm{Ca}^{2+}$-activated ion transporters in GI epithelial cells. In addition, the application of muscarinic agonists was observed to lead to an increase in $\left[\mathrm{Ca}^{2+}\right]_{\mathrm{cyt}}$ in secretory cells and promote GI anion secretion (22). However, this phenomenon has been extensively studied in other types secretory cells, such as the secretory cells in the avian basal gland (21).

Overall, the $\mathrm{Ca}^{2+}$ signaling and anion secretion mechanisms are of important clinical relevance and need to be further elucidated. In cystic fibrosis (CF), certain calcium agonists stimulate $\mathrm{Ca}^{2+}$-activated $\mathrm{Cl}^{-}$channel (CaCC)-dependent and $\mathrm{CF}$ transmembrane conductance regulator (CFTR)-independent secretion and agents that stimulate $\mathrm{Ca}^{2+}$ signaling may be used therapeutically to restore ion and fluid secretion defects (23). Conversely, in certain other types of GI disease, such as intestinal inflammation and diarrhea, inhibition of intracellular $\mathrm{Ca}^{2+}$ signaling may have therapeutic potential to ameliorate excessive fluid secretion $(24,25)$ (Table I). Therefore, in the present review, the current state of knowledge regarding $\mathrm{Ca}^{2+}$ signaling in the regulation of GI epithelial anion secretion and the associated GI disorders was summarized.

\section{General aspects of GI epithelial anion secretion}

GI epithelial $\mathrm{HCO}_{3}^{-}$secretion. GI epithelial bicarbonate $\left(\mathrm{HCO}_{3}^{-}\right)$is produced on the surface GI epithelial cells and secreted to the luminal side of the epithelium; it isinvolved in the formation of gastrointestinal mucus with a slightly alkaline $\mathrm{pH}$ (12). The basolateral side of electroneutral $\mathrm{Na}^{+}$-coupled $\mathrm{HCO}_{3}{ }^{-}$cotransporter is one of the important transporters for $\mathrm{HCO}_{3}{ }^{-}$absorption (12). With the help of the carbonic anhydrase, the $\mathrm{HCO}_{3}{ }^{-}$is taken up and it is also generated inside the cells (26).

To date, several pathways for the export of $\mathrm{HCO}_{3}{ }^{-}$into the luminal side of the GI mucosa have been elucidated: i) The CFTR or the $\mathrm{CaCC}$ is able to promote electrogenic $\mathrm{HCO}_{3}$ efflux, ii) luminal electroneutral anion $/ \mathrm{HCO}_{3}{ }^{-}$exchangers have been confirmed to contribute to the transport of $\mathrm{HCO}_{3}{ }^{-}$and iii) $\mathrm{HCO}_{3}^{-}$may betransported via the short-chain fatty acids (SCFA) $/ \mathrm{HCO}_{3}{ }^{-}$exchanger in the colon $(27,28)$. Electroneutral secretion of $\mathrm{HCO}_{3}{ }^{-}$is paralleled by the activity of $\mathrm{Na}^{+} / \mathrm{H}^{+}$ exchanger-3 (29). Furthermore, the luminal $\mathrm{Cl}^{-}$channels, as a recycling pathway for $\mathrm{Cl}^{-}$, are important for $\mathrm{HCO}_{3}{ }^{-}$secretion and they may serve in the electrogenic secretion of $\mathrm{HCO}_{3}{ }^{-}$via the luminal $\mathrm{Cl}^{-} / \mathrm{HCO}_{3}{ }^{-}$antiporters (27). One of the $\mathrm{Cl}^{-}$channels, CFTR, which is located on the apical side, was clearly demonstrated to be involved in the response of $\mathrm{HCO}_{3}{ }^{-}$secretion in the intestine a pancreatic duct (30). Besides the CFTR, $\mathrm{Ca}^{2+}$, cAMP and cGMP were indicated to induce $\mathrm{HCO}_{3}{ }^{-}$secretion in the small intestine (31). Current data has also demonstrated that the CFTR is involved in the regulation of the intracellular $\mathrm{pH}$ and that the expression and function of $\mathrm{Cl}^{-} / \mathrm{HCO}_{3}{ }^{-}$exchangers and down-regulated in adenoma were regulated by the CFTR (32). Of note, CFTR is necessary for $\mathrm{HCO}_{3}{ }^{-}$secretion in numerous other epithelial tissues as well (33). Thus, it is likely that the CFTR contributes to anion secretion and control of the luminal $\mathrm{pH}$ in the entire GI tract, but in the mammalian colon, the SCFA-dependent $\mathrm{HCO}_{3}$ secretion is the primary mechanism of $\mathrm{HCO}_{3}{ }^{-}$secretion (34). Well-regulated $\mathrm{HCO}_{3}{ }^{-}$secretion is critical for the mucosal defense against luminal acid due to its neutralization effect in the upper GI tract and against bacteria in the lower GI tract due to its stimulation of mucus secretion and maintenance of the intestinal barrier function (35). Aside from mechanisms of mucosal protection, normal $\mathrm{HCO}_{3}{ }^{-}$secretion in the small intestine is assumed to establish and maintain an optimal $\mathrm{pH}$ for the activity of luminal digestive enzymes (35). The small intestine is in an alkaline range of $\mathrm{pH}$ 6.7-8.0, which is the best $\mathrm{pH}$ value for the optimal activity of pancreatic enzymes (36). The duodenum in particular is an important organ exerting $\mathrm{pH}$ control for enzymatic digestion (37).

Defective intestinal $\mathrm{HCO}_{3}{ }^{-}$secretion has been indicated to be a risk factor for intestinal inflammation and peptic ulcer diseases (38). Furthermore, intestinal $\mathrm{HCO}_{3}{ }^{-}$secretion has been critically involved in the pathophysiology of acute infectious diarrhea (39). Cholera and numerous other acute diarrheal illnesses may increase the intestinal secretion and 


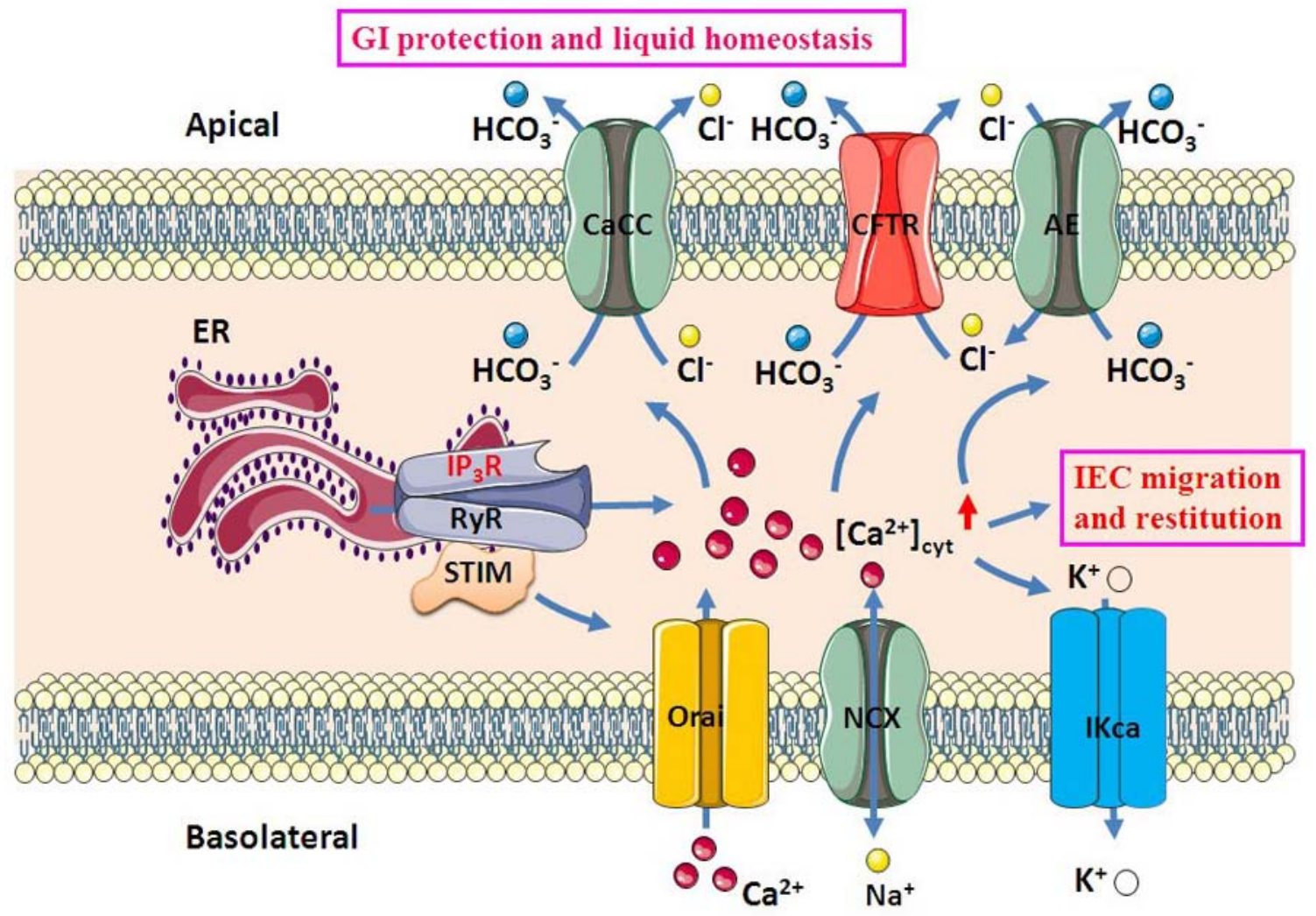

Figure 1. $\mathrm{Ca}^{2+}$-mediated GI epithelial anion secretion. An increase in $\left[\mathrm{Ca}^{2+}\right] c y t$ resulted from intracellular $\mathrm{Ca}^{2+}$ release through IP3R or RyR on the ER and extracellular $\mathrm{Ca}^{2+}$ entry through Orai and $\mathrm{NCX}$ on the plasma membrane stimulates apical CaCC, AE and CFTR, as well as basolateral IKCa. Ca ${ }^{2+}$ signaling activates IEC migration and restitution and stimulates $\mathrm{HCO}_{3}{ }^{-}$and $\mathrm{Cl}^{-}$secretion, which induces epithelial protection and liquid homeostasis, respectively. $\mathrm{CaCC}, \mathrm{Ca}^{2+}$-activated $\mathrm{Cl}^{-}$channel; AE, anion exchange; CFTR, cystic fibrosis transmembrane conductance regulator; IKCa, intermediate-conductance $\mathrm{Ca}^{2+}$-activated $\mathrm{K}^{+}$channel; ER, endoplasmic reticulum; RyR, ryanodine receptor; IP3R, inositol triphosphate receptor; STIM, stromal interaction molecule; Orai, ORAI calcium release-activated calcium modulators; NCX, $\mathrm{Na}^{+} / \mathrm{Ca}^{2+}$ exchangers; IEC, intestinal epithelial cell; GI, gastrointestinal.

loss of $\mathrm{HCO}_{3}^{-}$, which may result in a severe $\mathrm{HCO}_{3}^{-}$deficit and metabolic acidosis (40). Defective GI epithelial $\mathrm{HCO}_{3}{ }^{-}$secretion has been critically implicated in the pathogenesis of CF (30). A previous study examining the human duodenum indicated a CFTR-dependent alkaline transport in subjects without $\mathrm{CF}$, which was absent in patients with $\mathrm{CF}(41)$. Furthermore, electrogenic $\mathrm{HCO}_{3}^{-}$secretion was detected in the colon of mice without $\mathrm{CF}$, while it was absent in mice with $\mathrm{CF}$ (42). The defective $\mathrm{HCO}_{3}{ }^{-}$transport in $\mathrm{CF}$ may be crucial for the severity of the symptoms of CF (43). Defective $\mathrm{HCO}_{3}{ }^{-}$transport probably causes obstruction of the pancreatic duct and exocrine pancreatic insufficiency (44). Impaired duodenal $\mathrm{HCO}_{3}{ }^{-}$production and failure to buffer gastric acid is responsible for an increased incidence of epigastric pain and morphological changes in the duodenum of patients with CF (45).

GI epithelial $\mathrm{Cl}^{-}$secretion. In GI physiology, fluid secretion has a critical role and is driven by active $\mathrm{Cl}^{-}$transport from the basolateral to the apical side of enterocytes (46). The basolateral $\mathrm{Na}^{+}-\mathrm{K}^{+}-2 \mathrm{Cl}^{-}$cotransporter (NKCC1) is one of the important transporters for $\mathrm{Cl}^{-}$secretion (47). The rate secretion of $\mathrm{Cl}^{-}$is regulated by the activity of NKCC1, which is dependent on the intracellular $\mathrm{Cl}^{-}$concentration, cell swelling and probably phosphorylation (47). It has also been confirmed that the cAMP-activated KVLQT1/KCNE3 and $\mathrm{Ca}^{2+}$-activated $\mathrm{K}^{+}$ channels are able to maintain $\mathrm{Cl}^{-}$transport (48). The basolateral
$\mathrm{Cl}^{-}$is taken up by NKCC; however, its exit is primarily via the apical CFTR. Channels such as $\mathrm{CaCC}$ and other $\mathrm{Cl}^{-}$channels may also take part in apical $\mathrm{Cl}^{-}$secretion (49). $\mathrm{Na}^{+}$and water follow via a paracellular route (50). These ion and fluid transports initiated by pathogens (e.g., cholera toxin and rotavirus) involve multiple factors, such as 5-HT, substance P, $\mathrm{ACh}$ and vasoactive intestinal peptide, as well as the release of inflammatory mediators from mast cells and neutrophils [e.g. interleukins (ILs) and prostaglandins] (51). Ion and fluid secretion may be activated by different mechanisms that involve second messengers (cAMP, cGMP or $\mathrm{Ca}^{2+}$ ) to activate membrane ion channels (20).

Differences between GI epithelial secretion of $\mathrm{Cl}^{-}$and $\mathrm{HCO}_{3}$. It is generally assumed that the GI epithelial $\mathrm{HCO}_{3}{ }^{-}$and $\mathrm{Cl}^{-}$secretion have the same regulatory mechanisms (52). However, this notion requires to be confirmed through a systematic comparison between them (52). As mentioned earlier, GI epithelial $\mathrm{Cl}^{-}$and $\mathrm{HCO}_{3}{ }^{-}$secretion is mainly controlled by cAMP and $\mathrm{Ca}^{2+}$ signaling, which may interact and cross-talk to regulate epithelial ion transport $(13,27)$. Previous studies have demonstrated that most well-known secretagogues, including 5-HT, ACh, forskolin and $\mathrm{PGE}_{2}$, stimulate intestinal $\mathrm{HCO}_{3}{ }^{-}$and $\mathrm{Cl}^{-}$secretion in parallel (53-55). However, whether epithelial $\mathrm{HCO}_{3}{ }^{-}$and $\mathrm{Cl}^{-}$ secretion occur in parallel and whether they are regulated by the same or different signaling/mechanisms currently 
Table I. $\mathrm{Ca}^{2+}$-mediated GI epithelial anion secretion and the membrane ion channels involved.

\begin{tabular}{|c|c|c|c|c|}
\hline Ion channel & Mechanism & Expression & Related diseases & Author (refs) \\
\hline $\mathrm{HCO}_{3}^{-}$ & $\begin{array}{l}\text { Maintenance of intestinal barrier } \\
\text { function. Mechanisms of mucosal } \\
\text { protection. Establishes and maintains } \\
\text { optimal pH for the activity of } \\
\text { luminal digestive enzymes }\end{array}$ & GI epithelial cells & $\begin{array}{l}\text { Intestinal inflammation, } \\
\text { peptic ulcers, acute } \\
\text { infectious diarrhea, } \\
\text { metabolic acidosis, CF, } \\
\text { obstruction of the } \\
\text { pancreatic duct, exocrine } \\
\text { pancreatic insufficiency, } \\
\text { CLD, IBD }\end{array}$ & $\begin{array}{l}\text { Chen et al (26) } \\
\text { Fei et al }(36) \\
\text { Kuna et al }(38) \\
\text { Gennari et al }(40) \\
\text { Ramos et al }(45)\end{array}$ \\
\hline $\mathrm{Cl}^{-}$ & $\begin{array}{l}\text { Transports the secreted fluid from the } \\
\text { lateral base to the apical side of } \\
\text { intestinal cells }\end{array}$ & $\begin{array}{l}\text { Basolateral } \\
\text { GI epithelial } \\
\text { cells }\end{array}$ & $\begin{array}{l}\text { Acute infectious } \\
\text { diarrhea, metabolic } \\
\text { acidosis, CLD, IBD }\end{array}$ & $\begin{array}{l}\text { Frizzell et al (27) } \\
\text { Mohammad- } \\
\text { Panah et al (49) }\end{array}$ \\
\hline CFTR & $\begin{array}{l}\text { Contributes to the secretion of anions } \\
\text { and fluids in enterotoxin-induced } \\
\text { secretory diarrhea }\end{array}$ & $\begin{array}{l}\text { Pancreas, epithelial } \\
\text { cells in airways, } \\
\text { intestinal tract }\end{array}$ & $\mathrm{CF}$ & $\begin{array}{l}\text { Goodman et al (66) } \\
\text { Deachapunya et al (67) }\end{array}$ \\
\hline $\mathrm{CaCC}$ & $\begin{array}{l}\text { May participate in anion secretion in } \\
\text { the mammalian GI epithelium }\end{array}$ & Intestinal tract & $\mathrm{CF}$ & $\begin{array}{l}\text { Caputo et al }(76) \\
\text { Yang et al (17) } \\
\text { Morris et al }(79) \\
\text { Kunzelmann et al (83) }\end{array}$ \\
\hline $\begin{array}{l}\text { Anion/ } \\
\mathrm{HCO}_{3}^{-} \\
\text {exchangers }\end{array}$ & $\begin{array}{l}\text { Protects gastric mucosa by combating } \\
\text { aggressive factors }\end{array}$ & $\begin{array}{l}\text { Apical membrane } \\
\text { of intestinal } \\
\text { epithelial cells }\end{array}$ & $\begin{array}{l}\text { Acute infectious diarrhea, } \\
\text { metabolic acidosis, IBD, } \\
\text { CLD, CF }\end{array}$ & $\begin{array}{l}\text { Singh et al }(92) \\
\text { Tang et al }(59) \\
\text { Smith et al }(94)\end{array}$ \\
\hline $\begin{array}{l}\text { SOC and } \\
\text { STIM/Orai } \\
\text { channels }\end{array}$ & $\begin{array}{l}\text { Gene expression, cell growth and } \\
\text { organ development }\end{array}$ & $\begin{array}{l}\text { Intestinal } \\
\text { epithelial cells }\end{array}$ & $\mathrm{CF}$ & $\begin{array}{l}\text { Rao et al (105) } \\
\text { Onodera et al (106) }\end{array}$ \\
\hline $\mathrm{K}_{\mathrm{Ca}}$ & $\begin{array}{l}\text { Contributes to the stabilization of } \\
\text { membrane voltage and provides } \\
\text { the driving force for electrogenic } \\
\text { anion transport }\end{array}$ & $\begin{array}{l}\text { Intestinal } \\
\text { epithelium }\end{array}$ & $\begin{array}{l}\text { CLD, IBD, secretory } \\
\text { diarrhea, } \mathrm{CF}\end{array}$ & $\begin{array}{l}\text { Julio-Kalajzić et al }(114) \\
\text { Dong et al }(121,127) \\
\text { Xie et al }(13) \\
\text { Assaha et al }(115) \\
\text { Wang et al }(116)\end{array}$ \\
\hline $\mathrm{NCX}$ & $\begin{array}{l}\text { Maintenance of } \mathrm{Ca}^{2+} \text { homeostasis in } \\
\text { a variety of tissues. Involved in the } \\
\mathrm{Ca}^{2+} \text {-dependent anion secretion }\end{array}$ & $\begin{array}{l}\text { Cardiomyocytes, } \\
\text { vascular cells, } \\
\text { neurons, small } \\
\text { intestinal } \\
\text { epithelial cells }\end{array}$ & $\begin{array}{l}\text { Intestinal inflammation, } \\
\text { acute infectious diarrhea, } \\
\text { metabolic acidosis, CF, } \\
\text { CLD, IBD }\end{array}$ & $\begin{array}{l}\text { Lee } \text { et al }(124) \\
\text { Seipet al }(126) \\
\text { Dong et al }(121,127) \\
\text { Kocks et al }(110)\end{array}$ \\
\hline
\end{tabular}

GI, gastrointestinal; $\mathrm{HCO}_{3}^{-}$, bicarbonate; $\mathrm{CF}$, cystic fibrosis; $\mathrm{CLD}$, congenital chloride diarrhea; IBD, inflammatory bowel disease; $\mathrm{Cl}^{-}$, chloride; CFTR, cystic fibrosis transmembrane conductance regulator; $\mathrm{CaCC}, \mathrm{Ca}^{2+}$-activated $\mathrm{Cl}^{-}$channel; SOC, store-operated calcium channels; $\mathrm{STIM}$, stromal interaction molecule; Orai, ORAI calcium release-activated calcium modulators; $\mathrm{K}_{\mathrm{Ca}}, \mathrm{Ca}^{2+}$-activated $\mathrm{K}^{+}$channel; $\mathrm{NCX}, \mathrm{Na}^{+} / \mathrm{Ca}^{2+}$ exchangers.

remains elusive. Notably, it has been indicated that both forskolin- and carbachol (CCh)-induced rat colonic $\mathrm{Cl}^{-}$secretion was inhibited by estrogen (56) and further studies by the current researchers revealed that estrogen stimulates duodenal bicarbonate secretion (DBS) in humans and mice without altering basal duodenal short-circuit current (ISc), an index primarily of epithelial $\mathrm{Cl}^{-}$secretion $(57,58)$. These results demonstrated that estrogen may have different roles in regulating intestinal $\mathrm{HCO}_{3}{ }^{-}$and $\mathrm{Cl}^{-}$secretion. These findings also suggest that $\mathrm{GI}$ epithelial $\mathrm{HCO}_{3}^{-}$and $\mathrm{Cl}^{-}$secretion may not be necessarily triggered in the same way or by identical signaling/mechanisms. Furthermore, a previous study by the current researchers revealed that calcium-sensing receptor $(\mathrm{CaSR})$ activation raises $\left[\mathrm{Ca}^{2+}\right]_{\text {cyt }}$; however, it reduces cAMP-induced exclusive duodenal $\mathrm{HCO}_{3}{ }^{-}$secretion without simultaneously altering duodenal $\mathrm{Cl}^{-}$secretion (13). Similarly, Tang et al (59) demonstrated that CaSR activation stimulated colonic $\mathrm{HCO}_{3}{ }^{-}$secretion via $\mathrm{SCFA} / \mathrm{HCO}_{3}{ }^{-}$and $\mathrm{Cl}^{-} / \mathrm{HCO}_{3}{ }^{-}$exchangers; however, it inhibited $\mathrm{Cl}^{-}$secretion via the cAMP/CFTR pathway. It may, therefore, be proposed that a different regulatory mechanism likely exists for GI epithelial $\mathrm{HCO}_{3}{ }^{-}$and $\mathrm{Cl}^{-}$secretion. While cAMP may have a critical role in CFTR-mediated $\mathrm{Cl}^{-}$secretion, $\mathrm{Ca}^{2+}$ signaling may be critical in anion $/ \mathrm{HCO}_{3}{ }^{-}$-mediated $\mathrm{HCO}_{3}{ }^{-}$secretion. 


\section{3. $\mathrm{Ca}^{2+}$ modulation of GI epithelial anion secretion}

Evidence for $\mathrm{Ca}^{2+}$-mediated anion secretion. Although $\mathrm{Ca}^{2+}$ may mediate epithelial anion secretion through the cAMP signaling pathway, growing lines of evidence indicate that $\mathrm{Ca}^{2+}$ signaling is able to mediate epithelial anion secretion in a cAMP-independent manner (19). The evidence is as follows: i) The increase in $\left[\mathrm{Ca}^{2+}\right]_{\text {cyt }}$ induced by stimulation of cholinergic muscarinic type 3 receptor (M3R) were indicated to be due to activation of basolateral $\mathrm{K}^{+}$channels, which enhanced the driving force for luminal anion exit (60); ii) $\mathrm{Ca}^{2+} / \mathrm{cal}_{\text {modulin }}$ and protein kinase $\mathrm{C}(\mathrm{PKC})$ was demonstrated to be involved in the $\mathrm{CCh}$-mediated regulation of luminal and basolateral $\mathrm{K}^{+}$channels (61); iii) several previous studies suggested a contribution of $\mathrm{Ca}^{2+} / \mathrm{PKC}$ to CFTR activation $(62,63)$; and iv) activation of muscarinic receptors resulted in an increase in $\left[\mathrm{Ca}^{2+}\right]_{\text {cyt }}$; however, it decreased cAMP levels, which indeed triggered $\mathrm{Ca}^{2+}$-dependent duodenal transepithelial $\mathrm{HCO}_{3}{ }^{-}$secretion (13). Since cAMP-mediated ion transport has been extensively reviewed (64), the present study focused on $\mathrm{Ca}^{2+}$-mediated GI epithelial anion secretion and the membrane ion channels involved.

Apical CFTR. CFTR is expressed in different tissue types, including the pancreas, epithelial cells in the airways, GI tract and other fluid-transporting tissues (30). CF is caused by mutations in the CFTR gene, resulting in impaired $\mathrm{Cl}^{-}$and $\mathrm{HCO}_{3}{ }^{-}$transport and plasma membrane targeting (65). CFTR is mainly located in the luminal membrane of enterocytes and has a major role to contribute to the secretion of anions and fluid in enterotoxin-induced secretory diarrheas such as cholera (66). Numerous lines of solid evidence suggest a pivotal role for CFTR in GI anion and fluid secretion $(27,30,65,66)$.

Numerous in vitro studies have indicated that the application of glibenclamide and 5-nitro-2-(3-phenylpropylamino) benzoic acid further inhibited the $\mathrm{PGE}_{2}$ and cAMP-mediated increase in $I_{\mathrm{sc}}$ and anion secretion in GI epithelial sheets and cell lines $(67,68)$. Mice with gene ablation of CFTR developed intestinal obstruction $(69,70)$. The resultant characteristic ion transport impairment resulted in defective intestinal anion and fluid secretion and increased fluid absorption (71). In CFTR-null mice, increased expression of alternative $\mathrm{Cl}^{-}$ channels was present and the development of mild intestinal symptoms was observed (72). Furthermore, in CFTR-knockout mice, cholera toxin failed to cause massive fluid secretion through CFTR-dependent protein (72). CFTR has long been considered a primarily cAMP-activated $\mathrm{Cl}^{-}$channel to activate GI epithelial anion secretion (30). The majority of studies have confirmed that CFTR also responds to $\mathrm{Ca}^{2+}$-mobilizing secretagogues and contributes substantially to cholinergic and purinergic responses in native tissues $(30,62)$.

CFTR channels may be stimulated by the $G$ protein-coupled receptor-mediated signal via Gq protein $\alpha$ subunit, further activating $\mathrm{Ca}^{2+}$-dependent adenylyl cyclase and tyrosine kinases, and by inhibition of protein phosphatase type 2A (PP2A) (72). For instance, the M3R couples strongly to $G_{\alpha q}$. Stimulation of M3R produces diacylglycerol and $\mathrm{IP}_{3}$ to activate PKC and mobilize intracellular $\mathrm{Ca}^{2+}$, which in turn activates the proline-rich tyrosine kinase $2 / \mathrm{Src}$ complex (62). Src stimulates CFTR activity by phosphorylating it directly and inhibiting its dephosphorylation through the inactivation of PP2A (62). Under basal conditions, constitutive $\mathrm{Ca}^{2+}$ entry through storeoperated $\mathrm{Ca}^{2+}$ channels partially activates adenylyl cyclase and induces tonic CFTR activity (62).

A recent in vitro study by the current researchers revealed that the stimulation of mouse duodenal $\mathrm{I}_{\mathrm{sc}}$ by $\mathrm{CCh}$ was significantly inhibited in a $\mathrm{Ca}^{2+}$-free solution (17). After the application of $\mathrm{CCh}$, the intracellular calcium was significantly increased; however, there was no increase cAMP and compared to the CFTR-knockout mice. $\mathrm{CCh}$-induced $\mathrm{Ca}^{2+}$ was involved in the duodenal $\mathrm{Cl}^{-}$and $\mathrm{HCO}_{3}{ }^{-}$secretion in wild-type mice. The $\mathrm{CCh}$-induced intracellular calcium signaling also stimulated the phosphorylation of CFTR and promoted the CFTR transport to the plasma membrane of duodenal epithelial cells. Furthermore, $\mathrm{CCh}$ induced duodenal ion secretion and stimulated PI3K/Akt signaling pathway in duodenal epithelium and all of these effects were attenuated by selective PI3K inhibitors. Therefore, a novel molecular mechanism of $\mathrm{Ca}^{2+}$ signaling in CFTR-mediated ion secretion via PI3K/Akt was indicated.

Rasmussen et al (73), revealed that cigarette smoking increased $\left[\mathrm{Ca}^{2+}\right]_{\text {cyt }}$-induced CFTR internalization, which was prevented by chelation of cytoplasmic $\mathrm{Ca}^{2+}$. Furthermore, this phenomenon was inhibited by the macrolide antibiotic bafilomycin A1, which inhibited cigarette smoking-induced $\mathrm{Ca}^{2+}$ release and prevented CFTR clearance from the plasma membrane, further linking cytoplasmic $\mathrm{Ca}^{2+}$ and CFTR internalization. Patel et al (74), also indicated that an increase in $\left[\mathrm{Ca}^{2+}\right]_{\text {cyt }}$ induced a reduction of cell surface CFTR expression. Therefore, CFTR appears to be the channel that is in charge of not cAMP-activated, $\mathrm{Ca}^{2+}$-activated $\mathrm{Cl}^{-}$and $\mathrm{HCO}_{3}{ }^{-}$secretion in human GI mucosa (30).

Apical CaCC. There is currently evidence that the $\mathrm{CaCC}$ are a further class of important $\mathrm{Cl}^{-}$channels that may participate in anion secretion in the mammalian GI epithelium (75). In luminal membranes of GI epithelia of subjects with and without $\mathrm{CF}, \mathrm{CaCC}$ are stimulated by $\mathrm{Ca}^{2+}$ ionophores and $\mathrm{Ca}^{2+}$-mobilizing secretagogues (76), including acetylcholine, bradykinin, histamine, $\mathrm{CCh}$ and extracellular nucleotides adenosine triphosphate (ATP) and uridine triphosphate (UTP) $(77,78)$. In mice with CF, the expression of $\mathrm{Ca}^{2+}$-dependent $\mathrm{Cl}^{-}$channels was detectable in the intestine and was age-dependent. In young mice (age, 2-3 weeks), $\mathrm{Cl}^{-}$ secretion was induced by carbachol in the small intestine (17). Furthermore, it was indicated that in non-CF and CF mouse pup crypts, the application of nonstructural protein 4 (NSP4) caused severe diarrhea (79). However, compared to the young $\mathrm{CF}$ mice, the NSP4-induced $\mathrm{Cl}^{-}$secretion was largely reduced in adult $\mathrm{CF}$ mice. These data further support that the expression and function of $\mathrm{CaCC}$ are age-dependent. Indeed, it was also revealed that the adult $\mathrm{CF}$ mice (age, 6-12 weeks) did not exhibit CFTR-dependent $\mathrm{Cl}^{-}$secretion; however, they did have a partial CFTR-independent duodenal $\mathrm{HCO}_{3}{ }^{-}$secretion in response to $\mathrm{CCh}$ (17). Therefore, $\mathrm{CaCC}$ may have an important role in the regulation of intestinal $\mathrm{Cl}^{-}$secretion in young $\mathrm{CF}$ mice and may be important for duodenal $\mathrm{HCO}_{3}{ }^{-}$secretion in adult $\mathrm{CF}$ mice.

The $\mathrm{Ca}^{2+}$-activated TMEM16A anion channel (or anoctamin 1) was reported to be able to conduct $\mathrm{HCO}_{3}{ }^{-}$upon a 
significant increase in cytosolic $\mathrm{Ca}^{2+}$ levels (80). However, the role of anoctamin 1 in GI epithelial anion secretion remains under debate (81). More recently, a study by the current researchers indicated that caffeine-stimulated $\mathrm{Ca}^{2+}$-dependent duodenal anion secretion was attenuated by niflumic acid and T16Ainh-A01, two selective CaCC blockers with different chemical structures, suggesting that the TMEM16A anion channel is likely one of the downstream effectors of $\mathrm{Ca}^{2+}$ signaling (82).

It has been demonstrated that a residual cholinergic $\mathrm{Cl}^{-}$ secretion was preserved in a subset of patients with CF with a mild phenotype (83). In T84 colonic carcinoma cells, the role of $\mathrm{CaCC}$ has also been characterized and it was indicated to be responsible for $\mathrm{Ca}^{2+}$-mediated $\mathrm{Cl}^{-}$secretion in these cells (83). However, other studies suggested that the integrated function of CFTR is important for $\mathrm{CaCC}$ (84), as $\mathrm{Ca}^{2+}$-dependent cholinergic $\mathrm{Cl}^{-}$secretion was able to be completely inhibited by the deactivation of CFTR (85). All those results suggest that residual cholinergic $\mathrm{Cl}^{-}$secretion in $\mathrm{CF}$ tissues depends on the residual function of mutant CFTR. Therefore, although there is evidence for an alternative $\mathrm{CaCC}$ in the mouse colon and human colonic carcinoma cell lines, the promotion by $\mathrm{CaCC}$ is probably limited (86).

Apical anion $/ \mathrm{HCO}_{3}$ exchangers. It has been generally accepted that $\mathrm{HCO}_{3}{ }^{-}$secretion from the upper GI tract is important for the protection of normal mucosa (87). There are three anion $/ \mathrm{HCO}_{3}-$ exchangers: Solute carrier family 26 member 6 [SLC26A6; also known as putative anion transporter 1 (PAT1)], DAR and SLC4A9 (also known as anion exchange protein 4); all those channels contribute to the DBS to resist various aggressive factors, such as the acidic gastric output $(88,89)$. However, at least three distinct mechanisms of $\mathrm{HCO}_{3}{ }^{-}$secretion have been described in the distal colon of rats $(90,91)$ : i) $\mathrm{Cl}$-dependent: The $\mathrm{HCO}_{3}{ }^{-}$secretion mediated by a brush-border $\mathrm{Cl}^{-} / \mathrm{HCO}_{3}-$ exchange; ii) SCFA-dependent: $\mathrm{HCO}_{3}{ }^{-}$secretion as a result of activation of SCFA/ $\mathrm{HCO}_{3}{ }^{-}$exchange; and iii) cAMP-induced: $\mathrm{HCO}_{3}{ }^{-}$secretion associated with a CFTR (91).

As $\mathrm{Cl}^{-} / \mathrm{HCO}_{3}{ }^{-}$exchanger was expressed on the apical membrane of the small intestinal epithelium and likely has a role in secretagogue-stimulated DBS $(92,93)$, its possible involvement in estrogen-stimulated DBS was assessed in a study by the current researchers (94). The results suggested that estradiol $\left(\mathrm{E}_{2}\right)$ indeed stimulated murine DBS, which was attenuated by 4,4'-diisothiocyanostilbene-2-2'-disulfonic acid, a commonly used inhibitor of $\mathrm{Cl}^{-} / \mathrm{HCO}_{3}{ }^{-}$exchanger. $\mathrm{E}_{2}$ was also able to increase $\left[\mathrm{Ca}^{2+}\right]_{\mathrm{cyt}}$ in duodenal epithelial cells expressing estrogen receptor, whereas 1,2-Bis (2-aminophenoxy) ethane- $N, N, N^{\prime}, N^{\prime}$-tetraacetic acid tetrakis (acetoxymethyl ester) (BAPTA-AM) one of an intracellular calcium chelator inhibited the $\mathrm{E}_{2}$-stimulated murine DBS. It was therefore suggested that the activation of estrogen receptor stimulates the $\mathrm{Ca}^{2+}$-dependent DBS via $\mathrm{Cl}^{-} / \mathrm{HCO}_{3}{ }^{-}$exchanger.

Colonic bicarbonate secretion (CBS) is closely linked to electrolyte movement and overall fluid in the colon (59). As mentioned earlier, CaSR activation increases $\left[\mathrm{Ca}^{2+}\right]_{\text {cyi }}$, however, it decreases intracellular cAMP production. Consistently, Tang et al (59) reported that CaSR activation inhibited cAMP-activated CBS; however, it increased the lumen $\mathrm{Cl}^{-}$- and SCFA-dependent CBS. Consequently, upon activation of electroneutral $\mathrm{Cl}^{-} / \mathrm{HCO}_{3}{ }^{-}$and $\mathrm{SCFA} / \mathrm{HCO}_{3}{ }^{-}$exchangers, CaSR stimulated CBS; by contrast, if forskolin-stimulated electrogenic CFTR-mediated $\mathrm{HCO}_{3}{ }^{-}$conductance dominated, CaSR inhibited CBS. Consistently with the results on the $\mathrm{Ca}^{2+}$-mediated regulation of $\mathrm{Cl}^{-} / \mathrm{HCO}_{3}{ }^{-}$exchanger-mediated DBS reported by the current researchers (13), these results further suggest a critical role of $\mathrm{Ca}^{2+}$ signaling in the regulation of $\mathrm{Cl}^{-} / \mathrm{HCO}_{3}{ }^{-}$and SCFA/ $/ \mathrm{HCO}_{3}{ }^{-}$exchanger-mediated CBS (59). Therefore, modulation of CaSR activity may provide a new therapeutic approach to correct $\mathrm{HCO}_{3}{ }^{-}$deficits and metabolic acidosis, a primary cause of morbidity and mortality in acute infectious diarrheal illnesses (59). However, Lamprecht et al (95) reported on $\mathrm{Ca}^{2+}$-mediated inhibition of colonic DRA. Both the calcium ionophore A23187 and UTP that increased $\mathrm{Ca}^{2+}$ were able to inhibit DRA in these cells.

Basolateral store-operated channels and stromal interaction molecule (STIM)/Orai calcium release-activated calcium modulators. Store-operated calcium channels (SOC) are a major pathway for calcium signaling in virtually all mammalian cells and involved a variety of functions, including gene expression, cell growth and organ development (96-98). The SOC is stimulated by the diverse set of surface receptors via depletion of the $\mathrm{Ca}^{2+}$ concentration from the ER (99). The stromal interaction molecule (STIM) proteins were identified as the $\mathrm{ER} \mathrm{Ca}^{2+}$ sensors and the Orai proteins as store-operated channels and since then, rapid progress has been made in the elucidation of the unique mechanisms of store-operated calcium entry (SOCE) (99). The role of STIM1/Orai signaling was previously studied mostly in nonpolarized cells, such as lymphocytes $(100,101)$ or nonconfluent 293 cells $(102,103)$. However, only a few studies have assessed the function of STIM1/Orai signaling in polarized GI epithelia (104-106). In the human colonic tumor cell line NCM460, STIM1 stimulated by the emptying of intracellular $\mathrm{Ca}^{2+}$ stores after the production of cAMP (104). In addition, in the intestinal epithelial cell (IEC)-6 cell line from rat intestinal crypts, STIM1/Orai was indicated to have a role in wound healing (105). In the rat colonic epithelium, STIM1/Orai was identified as a key component of intracellular $\mathrm{Ca}^{2+}$ signaling involved in the regulation of both apical and basolateral $\mathrm{Ca}^{2+}$ influx (106).

Although the critical role of $\mathrm{Ca}^{2+}$ signaling in GI epithelial anion secretion is well-known (13), the mechanisms by which $\left[\mathrm{Ca}^{2+}\right]_{\text {cyt }}$ homeostasis in GI epithelial cells is controlled remain to be fully elucidated (11). Under normal physiological conditions, in non-excitable epithelial cells, the occurrence of $\mathrm{Ca}^{2+}$ entry mainly depends on the SOC (99). In non-excitable cells, agonists induce $\mathrm{Ca}^{2+}$ signaling mostly depending on the intracellular $\mathrm{Ca}^{2+}$ release mainly from the ER and $\mathrm{Ca}^{2+}$ influx from the extracellular medium (107). $\mathrm{IP}_{3}$-sensitive and ryanodine-sensitive $\mathrm{Ca}^{2+}$ stores have been identified within the ER $(108,109)$. The former is activated by the binding of $\mathrm{IP}_{3}$ to $\mathrm{IP}_{3} \mathrm{R}$, while the latter is activated by the binding of ryanodine to RyR to induce $\mathrm{ER} \mathrm{Ca}^{2+}$ release into the cytosol (110).

The $\mathrm{IP}_{3} \mathrm{R}$-mediated $\mathrm{Ca}^{2+}$ influx pathway was reported to have a role in the regulation of GI epithelial anion secretion $(109,111)$. Similarly, a study by the current researchers indicated that muscarinic receptors were activated after the application of $\mathrm{CCh}$ and induced mouse intestinal $\mathrm{Cl}^{-}$secretion, which was significantly inhibited by selective SOC blockers added to the serosal side of duodenal tissues in a $\mathrm{Ca}^{2+}$-free 
serosal solution (82). Furthermore, the study revealed that calcium release-activated calcium/Orai channels may represent the molecular candidate of SOC involved in the CCh-induced increase of intracellular $\mathrm{Ca}^{2+}$ in GI epithelium. As the underlying mechanisms of RyR-mediated $\mathrm{ER} \mathrm{Ca}^{2+}$ release as an important component of SOCE to contribute to GI epithelial anion secretion had remained elusive, the role of $\mathrm{RyR} / \mathrm{Ca}^{2+}$ storage was also further investigated by Dong et al (82). The results suggested that caffeine, a selective RyR activator, markedly increased mouse intestinal $\mathrm{Cl}^{-}$and $\mathrm{HCO}_{3}{ }^{-}$secretion. However, this process was suppressed by $\mathrm{Ca}^{2+}$-free serosal solutions and selective blockers of $\mathrm{SOC} / \mathrm{Ca}^{2+}$ and knockdown of the protein expression of Orail channels also inhibited the $\mathrm{Cl}^{-}$and $\mathrm{HCO}_{3}^{-}$secretion on the serosal side of duodenal tissue. Furthermore, the caffeine-induced anion secretion was inhibited by ER $\mathrm{Ca}^{2+}$ chelator and RyR blockers (82). In addition, the protein expression of STIM1 and Orail was detected. In IEC cells, the caffeine-induced SOCE was attenuated by selective SOC inhibitor (82).

It was therefore concluded that the RyR/Orai $1 / \mathrm{Ca}^{2+}$ signaling on the basolateral side has a critical role in the regulation of GI epithelial anion secretion (67). Lefkimmiatis et al (112) indicated that in a newly identified type of SOC termed 'store-operated cAMP signaling' (SOcAMPS), the luminal ER $\mathrm{Ca}^{2+}$ sensor STIM1 does not depend on changes in $\left[\mathrm{Ca}^{2+}\right]_{\text {cyt. }}$. The decreasing free $\mathrm{Ca}^{2+}$ concentration within the ER lumen induces a rise in intracellular cAMP. Therefore, they proposed the SOcAMPS, in which the content of internal $\mathrm{Ca}^{2+}$ stores is directly connected to cAMP signaling through a process that involves STIM1. Subsequently, Nichols et al (113) determined that in T84 colonic cells, the $\mathrm{I}_{\mathrm{sc}}$, cAMP and PKA activity was increased under $\mathrm{Ca}^{2+}$-free conditions after treatment with $\mathrm{Ca}^{2+}$-releasing agonist $\mathrm{CCh}$ and $\mathrm{Ca}^{2+}$ ionophore and suppressed by pre-treatment with BAPTA-AM. Furthermore, the effects of ER $\mathrm{Ca}^{2+}$ store depletion on cAMP/PKA activity were attenuated by $\mathrm{Ca}^{2+}$ entering from the extracellular space, indicating that the production of cAMP decreased after $\mathrm{Ca}^{2+}$ influx. They proposed that a discrete component of the ' $\mathrm{Ca}^{2+}$-dependent' secretory activity in the colon is derived from cAMP generated through SOcAMPS. These studies further support the notion that $\mathrm{Ca}^{2+}$ and cAMP signaling may independently trigger epithelial ion transport.

Basolateral $\mathrm{Ca}^{2+}$-activated $\mathrm{K}^{+}$channels $\left(K_{c a}\right)$. In GI epithelial cells, $\mathrm{K}^{+}$channels are important in the intestinal epithelium, contribute to the stabilization of membrane voltage and provide the driving force for electrogenic anion transport (114). The concept that cholinergic agents promote the intestinal $\mathrm{Cl}^{-}$secretion via the activation of membrane $\mathrm{K}^{+}$conductance and maintain the cellular $\mathrm{Cl}^{-}$transport has been widely accepted (115). Certain cholinergic agents, such as CCh, activate muscarinic receptors or acetylcholine raises the $\left[\mathrm{Ca}^{2+}\right]_{\mathrm{cyt}}$, which activates $\mathrm{K}_{\mathrm{Ca}}$ conductance and secondarily stimulates $\mathrm{Cl}^{-}$secretion via the apical CFTR (116). Therefore, basolateral $\mathrm{K}^{+}$channels hyperpolarize apical membrane potential and increase the electrical driving force for anion $\left(\mathrm{Cl}^{-}\right.$and $\left.\mathrm{HCO}_{3}{ }^{-}\right)$ secretion to maintain electroneutrality.

To date, three different subtypes of $\mathrm{K}_{\mathrm{Ca}}$ channels expressed on colonic surface and crypt cells have been identified: Large-conductance $\mathrm{K}_{\mathrm{Ca}}$ channels, intermediate-conductance $\mathrm{K}_{\mathrm{Ca}}$ channels $\left(\mathrm{IK}_{\mathrm{Ca}}\right)$ and small-conductance
$\mathrm{K}_{\mathrm{Ca}}$ channels $(117,118)$. Among them, $\mathrm{IK}_{\mathrm{Ca}}$ channels have an important role in epithelial $\mathrm{Cl}^{-}$secretion. A selective blocker of $\mathrm{IK}_{\mathrm{Ca}}$ channels, clotrimazole, inhibited the $\mathrm{Cl}^{-}$secretion in intact colonic epithelium and human colonic T84 cells (119). In addition, it has been demonstrated that activation of CFTR alone is insufficient to evoke transepithelial $\mathrm{Cl}^{-}$secretion and that basolateral membrane $\mathrm{K}^{+}$channels are also necessary components of the secretory response (30). Therefore, basolateral membrane $\mathrm{K}_{\mathrm{Ca}}$ channels represent an important potential therapeutic target to increase $\mathrm{Cl}^{-}$secretion in patients with $\mathrm{CF}$.

While the expression and function of $\mathrm{K}_{\mathrm{Ca}}$ channels and their role in the regulation of duodenal epithelial ion transport and DBS in the duodenal epithelium have remained elusive, it is well known that $\left[\mathrm{Ca}^{2+}\right]_{\text {cyt }}$ has an important role in epithelial ion transport $(2,11)$; however, the underlying mechanisms of $\left[\mathrm{Ca}^{2+}\right]_{\text {cyt }}$ to induce duodenal $\mathrm{HCO}_{3}{ }^{-}$secretion, or indeed other ion transport systems, had not been explored in detail. Therefore, the functionality of $\mathrm{K}_{\mathrm{ca}}$ and their role in the regulation of duodenal mucosal ion transport were explored. A previous review by the current researchers provided evidence that $\mathrm{IK}_{\mathrm{Ca}}$ or intermediate conductance calcium-activated potassium channel protein 4/SK4 channels are located on the basolateral side of duodenal epithelial cells and are involved in the regulation of $\mathrm{Ca}^{2+}$-mediated duodenal $\mathrm{Cl}$ - and $\mathrm{HCO}_{3}{ }^{-}$secretion (120). Furthermore, it was indicated that clotrimazole, a selective blocker of basolateral $\mathrm{IK}_{\mathrm{Ca}}$, was able to inhibit $\mathrm{Ca}^{2+}$-mediated duodenal $\mathrm{Cl}^{-}$and $\mathrm{HCO}_{3}{ }^{-}$secretion, suggesting its potential utility as an anti-diarrheal drug for the treatment of secretory diarrhea $(13,121)$.

NCX. The plasma membrane NCX is an important membrane transporter and has a critical role in the maintenance of $\mathrm{Ca}^{2+}$ homeostasis in a variety of tissue types (122).

NCX is a bidirectional plasma membrane transporter and in each cycle, three $\mathrm{Na}^{+}$for one $\mathrm{Ca}^{2+}$ are transported in the opposite direction and this process depends on electrochemical gradients (123). The expression and function of NCX have been demonstrated in cardiomyocytes, vascular cells and neurons (124). They are able to function in a forward mode to excrete intracellular $\mathrm{Ca}^{2+}$ and in reverse mode to induce extracellular $\mathrm{Ca}^{2+}$ entry and various associated signal transduction pathways (124). NCX was previously reported to be expressed in small intestinal epithelial cells and to function in the forward mode that is involved in the absorption of $\mathrm{Ca}^{2+}$ into the bloodstream. However, NCX also has a role in GI epithelial anion secretion (125).

Seip et al (126), demonstrated an interaction between SOC and NCX in the rat colon, where the influx of $\mathrm{Na}^{+}$across SOC serves to reduce the driving force for $\mathrm{Ca}^{2+}$ extrusion via the NCX and thereby maintains the increase in $\left[\mathrm{Ca}^{2+}\right]_{\text {cyt }}$ during the induction of rat colonic anion secretion. Consistently, Kocks et al (110) reported a cross-talk between the depletion of intracellular $\mathrm{Ca}^{2+}$ stores and NCX, which may maintain a long-lasting increase in $\left[\mathrm{Ca}^{2+}\right]_{\text {cyt }}$ to amplify $\mathrm{Ca}^{2+}$-dependent colonic $\mathrm{Cl}^{-}$secretion. While it was demonstrated that muscarinic receptor induced the activation of $\left[\mathrm{Ca}^{2+}\right]_{\mathrm{cyt}}$ increases, which regulates anion secretion, the underlying mechanisms of $\mathrm{Ca}^{2+}$ remained largely elusive. A previous study by the current researchers determined whether NCX has a role in the regulation of duodenal mucosal anion secretion by controlling 
$\mathrm{Ca}^{2+}$ homeostasis (127). The results indicated that activation of muscarinic receptors stimulated NCX activity in a reverse mode to increase $\left[\mathrm{Ca}^{2+}\right]_{\text {cyt }}$ in epithelial cells, leading to $\mathrm{Ca}^{2+}$-dependent $\mathrm{HCO}_{3}{ }^{-}$and $\mathrm{Cl}^{-}$secretion (127). In conclusion, $\mathrm{NCX}$ has an important role in $\mathrm{Ca}^{2+}$-dependent anion secretion by controlling $\mathrm{Ca}^{2+}$ homeostasis in GI epithelial cells.

\section{Associated GI diseases}

Ulcers. Ulcers refer to mucosal injury reaching the submucosa in the GI tract (128). Peptic ulcers may develop in the stomach or proximal duodenum and at the margin of a gastroenterostomy, Meckel's diverticulum or the esophagus (128). Helicobacter pylori (H. pylori) infection, non-steroidal anti-inflammatory drugs and stress cause a large proportion of peptic ulcers (129). Since patients with ulcers usually have hyperchlorhydria, proton-pump inhibitors are used to inhibit gastric acid secretion, besides eradication of $H$.pylori infection with antibiotics (130). It is well established that GI epithelial $\mathrm{HCO}_{3}{ }^{-}$secretion is critical for defending the vulnerable epithelium against various aggressive factors (87). The mucus secreted on the surface of GI mucosa and the bicarbonate ions secreted by the GI epithelium form a mucous bicarbonate barrier (87). When $\mathrm{H}^{+}$in gastric acid diffuses to the stomach wall, it is neutralized by $\mathrm{HCO}_{3}{ }^{-}$secreted by epithelial cells (87). In this way, the surface of the gastric mucosa remains in a neutral or partially alkaline state, preventing gastric acid and pepsin from attacking the mucosa (131). The esophagus also requires $\mathrm{HCO}_{3}{ }^{-}$secretion to protect the epithelial surface from acid reflux (132). Furthermore, normal mucus release from GI epithelium requires concurrent $\mathrm{HCO}_{3}{ }^{-}$secretion, which is essential for the release of mucin molecules and their proper expansion on the surface of epithelium as well (133). As a matter of fact, DBS, as an important protector, has been confirmed in patients with duodenal ulcer whose acid-stimulated DBS is only $41 \%$ of that of healthy subjects (94). The defect in intestinal $\mathrm{HCO}_{3}{ }^{-}$secretion has further been indicated to be a risk factor for peptic ulcer diseases (134).

Additionally, normal colonic $\mathrm{HCO}_{3}^{-}$secretion is critical for the mucosal defense against bacteria in the lower GI tract (87). The luminal $\mathrm{pH}$ was indicated to be acidic in the colon of patients with ulcerative colitis (UC), which may be caused at least in part by disturbances in the ion transport in the inflamed colon (135). Therefore, it appears important to recover normal $\mathrm{GI}$ epithelial $\mathrm{HCO}_{3}{ }^{-}$secretion in patients with peptic ulcers and inflamed colon to prevent their recurrence. It is of growing interest to discover novel drugs to stimulate sufficient $\mathrm{GI}$ epithelial $\mathrm{HCO}_{3}{ }^{-}$secretion for mucosal protection as a potential adjuvant therapy for ulcer diseases or prevention of their recurrence.

$C F$. Epithelial $\mathrm{HCO}_{3}{ }^{-}$secretion is impaired in the GI tract of patients with $\mathrm{CF}$, suggesting a pivotal role of the CFTR in mediating epithelial $\mathrm{HCO}_{3}^{-}$secretion (64). Patients with $\mathrm{CF}$ usually have an epithelial $\mathrm{HCO}_{3}^{-}$deficit. As discussed earlier, while the CFTR is mainly triggered by the cAMP/PKA pathway, most of the channels involved in GI epithelial anion secretion, including $\mathrm{CaCC}$, anion exchangers, $\mathrm{K}_{\mathrm{Ca}}$ and even CFTR, may be generally triggered by $\mathrm{Ca}^{2+}$ signaling (136). For instance, the $\mathrm{CaCC}$ is stimulated by $\mathrm{Ca}^{2+}$ ionophores and $\mathrm{Ca}^{2+}$-mobilizing secretagogues in luminal membranes of GI epithelia from subjects with or without CF (136), including ACh, CCh, histamine, bradykinin, ATP and UTP $(77,78)$. Furthermore, a previous study by the current researchers demonstrated that adult $\mathrm{CF}$ mice exhibited a partial CFTR-independent duodenal $\mathrm{HCO}_{3}{ }^{-}$secretion in response to $\mathrm{CCh}$, although they did not display CFTR-dependent $\mathrm{Cl}^{-}$secretion (58). More recently, a study by the current researchers demonstrated that caffeine stimulated $\mathrm{Ca}^{2+}$-dependent duodenal anion secretion, which was able to be attenuated by selective $\mathrm{CaCC}$ blockers, suggesting that the $\mathrm{CaCC}$ is one of the downstream effectors of $\mathrm{Ca}^{2+}$ signaling (82). Therefore, after the cAMP-activated CFTR is impaired in CF, targeting the $\mathrm{Ca}^{2+}$-mediated pathway may be a potential adjuvant for CF therapy. Calcium ions have a critical role in the normal functioning of the gastrointestinal system (137). Certain calcium channel blockers were used to affect all of the organs of the gastrointestinal tract and may have therapeutic efficacy against esophageal spasm, mesenteric vascular insufficiency, irritable bowel syndrome, dyskinesis of the Sphincter of Oddi and insulinoma (137); however, this requires further intensive investigation.

Inflammatory bowel disease (IBD). IBD, including Crohn's disease and UC, is a group of chronic inflammatory disorders of the GI tract. Diarrhea is the most highly prevalent and debilitating symptom of IBD (138). The pathogenesis of IBD is multifactorial and involves variations in patients' genome, immune response, the intestinal microbiome and environmental factors to result in an excessive and abnormal host immune response (139). However, the change of expression and/or function of epithelial ion channels and transporters may result in electrolyte retention and water accumulation in the intestinal lumen, leading to diarrhea in IBD (139). IBD is a chronic inflammatory disorder with high complex endogenous inflammatory meditators, including IL- $1 \beta$, tumor necrosis factor- $\alpha$, interferon- $\gamma$, IL-6, monochloramine and nitric oxide (140). They may act on intestinal epithelial ion transport and smooth muscle (141). Furthermore, the colon of patients with UC has an acidic luminal $\mathrm{pH}$, which impairs the ion transport in the inflamed colon (142). Consistently, the expression of $\mathrm{Cl}^{-} / \mathrm{HCO}_{3}{ }^{-}$exchanger SLC26A3 (DRA) was reported to be markedly decreased in the inflamed colon (143). The expression of DRA was also indicated to be absent exclusively in UC patients, indicating inadequate membrane trafficking events $(144,145)$. Furthermore, in a recent genome-wide association study, a single-nucleotide polymorphism in the SLC26A3 gene was identified as a risk factor for UC development (146). A strong reduction in $\mathrm{Cl}^{-}$absorption was identified in parallel with a low expression of DRA in UC colonic crypts (147). Therefore, decreased DRA expression may lead to a deficient $\mathrm{Cl}^{-}$absorption in UC, which emphasizes the important role of DRA in UC-associated diarrhea (148).

Congenital chloride diarrhea (CLD). It is well established that DRA and PAT-1 are the two major transporters involved in apical $\mathrm{Cl}^{-} / \mathrm{HCO}_{3}{ }^{-}$exchange in the GI tract $(88,90)$. As mentioned above, loss of the expression and function of DRA may induce diarrheal disorders (143). However, mutations in the DRA gene that encode $\mathrm{Cl}^{-} / \mathrm{HCO}_{3}{ }^{-}$exchange cause a rare diarrheal disorder named CLD, which is associated with a high stool concentration of $\mathrm{Cl}^{-}$, metabolic alkalosis and physiologic 
evidence of an absence of $\mathrm{Cl}^{-} / \mathrm{HCO}_{3}{ }^{-}$exchange in the colon and ileum (149). Therefore, the characteristics of patients with CLD include voluminous diarrhea, massive loss of $\mathrm{Cl}^{-}$via the stool and metabolic alkalosis. Furthermore, the $\mathrm{pH}$ of the ileocolonic lumen in patients with IBD has been reported to be reduced due to limited $\mathrm{HCO}_{3}{ }^{-}$secretion (146). Since DRA serves as the major luminal intestinal $\mathrm{Cl}^{-} / \mathrm{HCO}_{3}{ }^{-}$exchanger responsible for bulk intestinal $\mathrm{Cl}^{-}$absorption and $\mathrm{HCO}_{3}{ }^{-}$secretion, DRA deficiency is one of the important factors in the pathogenesis CLD and IBD (147). Therefore, based on the reported $\mathrm{Ca}^{2+}$-mediated inhibition of colonic DRA, it may be speculated that inhibition of intracellular $\mathrm{Ca}^{2+}$ signaling may have therapeutic potential to improve excessive fluid secretion, thereby providing a novel research direction for the treatment of CLD and IBD.

\section{Conclusion}

GI epithelial anion and fluid transport have critical roles in maintaining normal physiological functions in the GI tract. Defective GI epithelial anion secretion has been critically implicated in the pathophysiology of ulcer diseases, CF, intestinal inflammation, diarrhea/constipation and even metabolic acidosis. Similarly, $\left[\mathrm{Ca}^{2+}\right]_{\text {cyt }}$ also has a critical role in the regulation of digestive functions. GI epithelial anion secretion is known to be controlled by several neuro-humoral factors, including $\mathrm{PGE}_{2}, \mathrm{ACh}$ and 5-HT. These factors mediate epithelial anion secretion mainly through $\mathrm{Ca}^{2+}$, cAMP and cGMP signaling pathways. Although multiple interactions exist between $\mathrm{Ca}^{2+}$ signaling and the cAMP pathway to trigger GI epithelial anion secretion, growing lines of evidence indicated that $\mathrm{Ca}^{2+}$ signaling may mediate epithelial anion secretion in a cAMP-independent manner. $\mathrm{Ca}^{2+}$ signaling modulates $\mathrm{GI}$ epithelial anion secretion through acting on CFTR, CaCC, $\mathrm{Cl}^{-} / \mathrm{HCO}_{3}{ }^{-}$exchanger, $\mathrm{SOC}, \mathrm{K}_{\mathrm{ca}}$ and $\mathrm{NCX}$. It was previously assumed that those channels and transporters involved in GI epithelial secretion of $\mathrm{Cl}^{-}$and $\mathrm{HCO}_{3}^{-}$are identical; however, emerging evidence suggests they are different. While cAMP may be a critical factor in CFTR-mediated $\mathrm{Cl}^{-}$secretion, $\mathrm{Ca}^{2+}$ signaling may have a critical role in $\mathrm{Cl}^{-} / \mathrm{HCO}_{3}{ }^{-}$-mediated $\mathrm{HCO}_{3}^{-}$secretion. Elucidation of the precise regulatory mechanisms of $\mathrm{Ca}^{2+}$-mediated GI epithelial $\mathrm{Cl}^{-}$and $\mathrm{HCO}_{3}{ }^{-}$secretion will markedly enhance the current knowledge of ion and fluid transport in the GI tract. Further investigation on the differences between GI epithelial secretion of $\mathrm{Cl}^{-}$and $\mathrm{HCO}_{3}^{-}$may provide novel potential drug targets to protect the upper GI tract against ulcer diseases and promote epithelial $\mathrm{HCO}_{3}$ secretion.

\section{Acknowledgements}

The authors thank Professor Biguang Tuo (Department of Gastroenterology, Affiliated Hospital to Zunyi Medical University, Zunyi, China) for his assistance with the grammar, spelling and formatting of the manuscript.

\section{Funding}

The current study was supported by research grants of the National Natural Science Foundation of China (no. 81660412 to RX and no. 81970541 to JYX).

\section{Availability of data and materials}

Not applicable.

\section{Authors' contributions}

WS, YH, JD, XY, JL, QD, QL and LL conceived the current review article. JX and RX were responsible for the collection and assembly of the articles/published data for inclusion and interpretation in this review. All authors were involved in the writing of the manuscript. All authors have read and approved the final manuscript.

\section{Ethics approval and consent to participate}

Not applicable.

\section{Patient consent for publication}

Not applicable.

\section{Competing interests}

The authors declare that they have no competing interests.

\section{References}

1. Berridge MJ, Lipp P and Bootman MD: The versatility and universality of calcium signalling. Nat Rev Mol Cell Biol 1: 11-21, 2000.

2. Clapham DE: Calcium signaling. Cell 131: 1047-1058, 2007.

3. Kristián $\mathrm{T}$ and Siesjö BK: Calcium in ischemic cell death. Stroke 29: 705-718, 1998.

4. Berridge MJ, Bootman MD and Roderick HL: Calcium signalling: Dynamics, homeostasis and remodelling. Nat Rev Mol Cell Biol 4: 517-529, 2003.

5. Dong Z, Saikumar P, Weinberg JM and Venkatachalam MA: Calcium in cell injury and death. Annu Rev Pathol 1: 405-434, 2006.

6. Romac JM, Shahid RA, Swain SM, Vigna SR and Liddle RA: Piezol is a mechanically activated ion channel and mediates pressure induced pancreatitis. Nat Commun 9: 1715, 2018.

7. Criddle DN, McLaughlin E, Murphy JA, Petersen OH and Sutton R: The pancreas misled: Signals to pancreatitis. Pancreatology 7: 436-446, 2007.

8. Lee PJ and Papachristou GI: New insights into acute pancreatitis. Nat Rev Gastroenterol Hepatol 16: 479-496, 2019.

9. Karlstad J, Sun Y and Singh BB: $\mathrm{Ca}(2+)$ signaling: An outlook on the characterization of $\mathrm{Ca}(2+)$ channels and their importance in cellular functions. Adv Exp Med Biol 740: 143-157: 2012.

10. Kinjo TG and Schnetkamp PPM: Ca2+ chemistry, storage and transport in biologic systems: An overview. Mol Biol Intell Unit, pp1-11, 1970.

11. Foskett JK, White $\mathrm{C}$, Cheung $\mathrm{KH}$ and Mak DO: Inositol trisphosphate receptor Ca2+ release channels. Physiol Rev 87: 593-658, 2007.

12. He J, Yang X, Guo Y, Zhang F, Wan H, Sun X, Tuo B and Dong H: $\mathrm{Ca}^{2+}$ signaling in $\mathrm{HCO}_{3}^{-}$secretion and protection of upper GI tract. Oncotarget 8: 102681-102689, 2017.

13. Xie R, Dong X, Wong C, Vallon V, Tang B, Sun J, Yang S and Dong $\mathrm{H}$ : Molecular mechanisms of calcium-sensing receptor-mediated calcium signaling in the modulation of epithelial ion transport and bicarbonate secretion. J Biol Chem 289: 34642-34653, 2014.

14. Abdulnour-Nakhoul S, Nakhoul HN, Kalliny MI, Gyftopoulos A, Rabon E, Doetjes R, Brown K and Nakhoul NL: Ion transport mechanisms linked to bicarbonate secretion in the esophageal submucosal glands. Am J Physiol Regul Integr Comp Physiol 301: R83-R96, 2011.

15. Kiela PR and Ghishan FK: Physiology of intestinal absorption and secretion. Best Pract Res Clin Gastroenterol 30: 145-159, 2016. 
16. Bachmann $\mathrm{O}$ and Seidler U: News from the end of the gut-how the highly segmental pattern of colonic $\mathrm{HCO}_{3}^{-}$transport relates to absorptive function and mucosal integrity. Biol Pharm Bull 34 794-802, 2011

17. Yang X, Wen G, Tuo B, Zhang F, Wan H, He J, Yang S and Dong $\mathrm{H}$ : Molecular mechanisms of calcium signaling in the modulation of small intestinal ion transports and bicarbonate secretion. Oncotarget 9: 3727-3740, 2017.

18. Tuo B, Wen G, Zhang Y, Liu X, Wang X, Liu X and Dong H: Involvement of phosphatidylinositol 3-kinase in cAMP- and cGMP-induced duodenal epithelial CFTR activation in mice. Am J Physiol Cell Physiol 297: C503-C515, 2009.

19. Ahuja M, Jha A, Maléth J, Park S and Muallem S: cAMP and $\mathrm{Ca}^{2+}$ signaling in secretory epithelia: Crosstalk and synergism. Cell Calcium 55: 385-393, 2014

20. Lee RJ and Foskett JK: cAMP-activated Ca2+ signaling is required for CFTR-mediated serous cell fluid secretion in porcine and human airways. J Clin Invest 120: 3137-3148, 2010.

21. Kallenberg LA: Calcium signalling in secretory cells. Arch Physiol Biochem 108: 385-390, 2000.

22. Lee MG, Ohana E, Park HW, Yang D and Muallem S: Molecular mechanism of pancreatic and salivary gland fluid and $\mathrm{HCO} 3$ secretion. Physiol Rev 92: 39-74, 2012.

23. Ambudkar IS: $\mathrm{Ca}^{2+}$ signaling and regulation of fluid secretion in salivary gland acinar cells. Cell Calcium 55: 297-305, 2014.

24. Linan-Rico A, Ochoa-Cortes F, Beyder A, Soghomonyan S, Zuleta-Alarcon A, Coppola V and Christofi FL: Mechanosensory signaling in enterochromaffin cells and 5-HT release: Potentia implications for gut inflammation. Front Neurosci 10: 564, 2016

25. Thiagarajah JR, Donowitz M and Verkman AS: Secretory diarrhoea: Mechanisms and emerging therapies. Nat Rev Gastroenterol Hepatol 12: 446-457, 2015.

26. Chen M, Praetorius J, Zheng W, Xiao F, Riederer B, Singh AK, Stieger N, Wang J, Shull GE, Aalkjaer C and Seidler U: The electroneutral $\mathrm{Na}^{+}: \mathrm{HCO}_{3}$ cotransporter $\mathrm{NBCn} 1$ is a major $\mathrm{pH}$ regulator in murine duodenum. J Physiol 590: 3317-3333, 2012.

27. Frizzell RA and Hanrahan JW: Physiology of epithelial chloride and fluid secretion. Cold Spring Harb Perspect Med 2: a009563, 2012.

28. Quinton PM: Role of epithelial $\mathrm{HCO}_{3}{ }^{-}$transport in mucin secretion: Lessons from cystic fibrosis. Am J Physiol Cell Physiol 299: C1222-C1233, 2010.

29. Furukawa O, Bi LC, Guth $\mathrm{PH}$, Engel E, Hirokawa $\mathrm{M}$ and Kaunitz JD: NHE3 inhibition activates duodenal bicarbonate secretion in the rat. Am J Physiol Gastrointest Liver Physiol 286: G102-G109, 2004

30. Saint-Criq V and Gray MA: Role of CFTR in epithelial physiology. Cell Mol Life Sci 74: 93-115, 2017.

31. Yang N, Garcia MA and Quinton PM: Normal mucus formation requires cAMP-dependent $\mathrm{HCO} 3$ - secretion and $\mathrm{Ca} 2+$-mediated mucin exocytosis. J Physiol 591: 4581-4593, 2013.

32. Chávez JC, Hernández-González EO, Wertheimer E, Visconti PE, Darszon A and Treviño CL: Participation of the $\mathrm{Cl}-/ \mathrm{HCO}(3)$-exchangers SLC26A3 and SLC26A6, the Clchannel CFTR, and the regulatory factor SLC9A3R1 in mouse sperm capacitation. Biol Reprod 86: 1-14, 2012.

33. Hug MJ, Tamada T and Bridges RJ: CFTR and bicarbonate secretion by [correction of to] epithelial cells. News Physio Sci 18: 38-42, 2003

34. Binder HJ, Rajendran V, Sadasivan V and Geibel JP: Bicarbonate secretion: A neglected aspect of colonic ion transport. J Clin Gastroenterol 39 (4 Suppl 2): S53-S58, 2005.

35. Feldman M: Gastric bicarbonate secretion in humans. Effect of pentagastrin, bethanechol, and 11,16,16-trimethyl prostaglandin E2. J Clin Invest 72: 295-303, 1983.

36. Fei G, Fang X, Wang GD, Liu S, Wang XY, Xia Y and Wood JD: Neurogenic mucosal bicarbonate secretion in guinea pig duodenum. Br J Pharmacol 168: 880-890, 2013.

37. Rune SJ: $\mathrm{pH}$ in the human duodenum. Its physiological and pathophysiological significance. Digestion 8: 261-268, 1973.

38. Kuna L, Jakab J, Smolic R, Raguz-Lucic N, Vcev A and Smolic M: Peptic ulcer disease: A brief review of conventional therapy and herbal treatment options. J Clin Med 8: 179, 2019.

39. Field M: Intestinal ion transport and the pathophysiology of diarrhea. J Clin Invest 111: 931-943, 2003

40. Gennari FJ and Weise WJ: Acid-base disturbances in gastrointestinal disease. Clin J Am Soc Nephrol 3: 1861-1868, 2008.

41. Pratha VS, Hogan DL, Martensson BA, Bernard J, Zhou R and Isenberg JI: Identification of transport abnormalities in duodenal mucosa and duodenal enterocytes from patients with cystic fibrosis. Gastroenterology 118: 1051-1060, 2000.
42. Xiao F, Li J, Singh AK, Riederer B, Wang J, Sultan A, Park H, Lee MG, Lamprecht G, Scholte BJ, et al: Rescue of epithelial $\mathrm{HCO} 3$ - secretion in murine intestine by apical membrane expression of the cystic fibrosis transmembrane conductance regulator mutant F508del. J Physiol 590: 5317-5334, 2012.

43. Ehre C, Ridley C and Thornton DJ: Cystic fibrosis: An inherited disease affecting mucin-producing organs. Int J Biochem Cell Biol 52: 136-145, 2014.

44. Wilschanski M and Novak I: The cystic fibrosis of exocrine pancreas. Cold Spring Harb Perspect Med 3: a009746, 2013.

45. Ramos AF, de Fuccio MB, Moretzsohn LD, Barbosa AJ, Passos Mdo C, Carvalho RS and Coelho LG: Cystic fibrosis, gastroduodenal inflammation, duodenal ulcer, and $H$. pylori infection: The 'cystic fibrosis paradox' revisited. J Cyst Fibros 12: 377-383, 2013.

46. Kuwahara A: Involvement of the gut chemosensory system in the regulation of colonic anion secretion. Biomed Res Int 2015: 403919, 2015

47. Markadieu N and Delpire E: Physiology and pathophysiology of SLC12A1/2 transporters. Pflugers Arch 466: 91-105, 2014.

48. Flores CA, Melvin JE, Figueroa CD and Sepúlveda FV: Abolition of Ca2+-mediated intestinal anion secretion and increased stool dehydration in mice lacking the intermediate conductance Ca2+-dependent K+ channel Kcnn4. J Physiol 583: 705-717, 2007.

49. Mohammad-Panah R, Ackerley C, Rommens J, Choudhury M, Wang Y and Bear CE: The chloride channel ClC-4 co-localizes with cystic fibrosis transmembrane conductance regulator and may mediate chloride flux across the apical membrane of intestinal epithelia. J Biol Chem 277: 566-574, 2002.

50. Argenzio RA, Whipp SC and Glock RD: Pathophysiology of swine dysentery: Colonic transport and permeability studies. J Infect Dis 142: 676-684, 1980.

51. Lakhan SE and Kirchgessner A: Neuroinflammation in inflammatory bowel disease. J Neuroinflammation 7: 37, 2010.

52. Park HW and Lee MG: Transepithelial bicarbonate secretion: Lessons from the pancreas. Cold Spring Harb Perspect Med 2: a009571, 2012

53. Kaji I, Akiba Y, Said H, Narimatsu K and Kaunitz JD: Luminal 5 -HT stimulates colonic bicarbonate secretion in rats. Br J Pharmacol 172: 4655-4670, 2015.

54. Sugamoto S, Kawauch S, Furukawa O, Mimaki TH and Takeuchi K: Role of endogenous nitric oxide and prostaglandin in duodenal bicarbonate response induced by mucosal acidification in rats. Dig Dis Sci 46: 1208-1216, 2001

55. Devor DC, Singh AK, Lambert LC, DeLuca A, Frizzell RA and Bridges RJ: Bicarbonate and chloride secretion in Calu-3 human airway epithelial cells. J Gen Physiol 113: 743-760, 1999.

56. Condliffe SB, Doolan CM and Harvey BJ: 17beta-oestradiol acutely regulates $\mathrm{Cl}$ - secretion in rat distal colonic epithelium. J Physiol 530: 47-54, 2001.

57. Tuo B, Wen G, Wei J, Liu X, Wang X, Zhang Y, Wu H, Dong X, Chow JY, Vallon V and Dong H: Estrogen regulation of duodenal bicarbonate secretion and sex-specific protection of human duodenum. Gastroenterology 141: 854-863, 2011.

58. Yang X, Guo Y, He J, Zhang F, Sun X, Yang S and Dong H: Estrogen and estrogen receptors in the modulation of gastrointestinal epithelial secretion. Oncotarget 8: 97683-97692, 2017.

59. Tang L, Peng M, Liu L, Chang W, Binder HJ and Cheng SX: Calcium-sensing receptor stimulates $\mathrm{Cl}(-)$ - and SCFA-dependent but inhibits CAMP-dependent HCO3(-) secretion in colon. Am J Physiol Gastrointest Liver Physiol 308: G874-G883, 2015.

60. Nathanson NM: Synthesis, trafficking, and localization of muscarinic acetylcholine receptors. Pharmacol Ther 119: 33-43, 2008.

61. Gustafsson JK, Lindén SK, Alwan AH, Scholte BJ, Hansson GC and Sjövall $\mathrm{H}$ : Carbachol-induced colonic mucus formation requires transport via $\mathrm{NKCCl}, \mathrm{K}^{+}$channels and CFTR. Pflugers Arch 467: 1403-1415, 2015

62. Billet A and Hanrahan JW: The secret life of CFTR as a calcium-activated chloride channel. J Physiol 591: 5273-5278, 2013.

63. Jia Y, Mathews CJ and Hanrahan JW: Phosphorylation by protein kinase $\mathrm{C}$ is required for acute activation of cystic fibrosis transmembrane conductance regulator by protein kinase A. J Biol Chem 272: 4978-4984, 1997.

64. Kiela PR and Ghishan FK: Ion transport in the intestine. Curr Opin Gastroenterol 25: 87-91, 2009. 
65. Shah VS, Ernst S, Tang XX, Karp PH, Parker CP, Ostedgaard LS and Welsh MJ: Relationships among CFTR expression, HCO3secretion, and host defense may inform gene- and cell-based cystic fibrosis therapies. Proc Natl Acad Sci USA 113: 5382-5387, 2016.

66. Goodman BE and Percy WH: CFTR in cystic fibrosis and cholera: From membrane transport to clinical practice. Adv Physiol Educ 29: 75-82, 2005.

67. Deachapunya C and O'Grady SM: Regulation of chloride secretion across porcine endometrial epithelial cells by prostaglandin E2. J Physiol 508: 31-47, 1998.

68. Hoffmann EK, Lambert IH and Pedersen SF: Physiology of cell volume regulation in vertebrates. Physiol Rev 89: 193-277, 2009.

69. Borowitz D and Gelfond D: Intestinal complications of cystic fibrosis. Curr Opin Pulm Med 19: 676-680, 2013.

70. Kelly T and Buxbaum J: Gastrointestinal manifestations of cystic fibrosis. Dig Dis Sci 60: 1903-1913, 2015.

71. Lavelle GM, White MM, Browne N, McElvaney NG and Reeves EP: Animal models of cystic fibrosis pathology: Phenotypic parallels and divergences. Biomed Res Int 2016: 5258727, 2016.

72. Li C, Dandridge KS, Di A, Marrs KL, Harris EL, Roy K, Jackson JS, Makarova NV, Fujiwara Y, Farrar PL, et al: Lysophosphatidic acid inhibits cholera toxin-induced secretory diarrhea through CFTR-dependent protein interactions. J Exp Med 202: 975-986, 2005.

73. Rasmussen JE, Sheridan JT, Polk W, Davies CM and Tarran R: Cigarette smoke-induced $\mathrm{Ca} 2+$ release leads to cystic fibrosis transmembrane conductance regulator (CFTR) dysfunction. J Biol Chem 289: 7671-7681, 2014.

74. Patel W, Moore PJ, Sassano MF, Lopes-Pacheco M, Aleksandrov AA, Amaral MD, Tarran R and Gray MA: Increases in cytosolic $\mathrm{Ca}^{2}+$ induce dynamin- and calcineurin-dependent internalisation of CFTR. Cell Mol Life Sci 76: 977-994, 2019.

75. He J, Yang X, Guo Y, Zhang F, Wan H, Sun X, Tuo B and Dong $\mathrm{H}$ : $\mathrm{Ca} 2+$ signaling in $\mathrm{HCO}_{3}{ }^{-}$secretion and protection of upper GI tract. Oncotarget 8: 102681-102689, 2017.

76. Caputo A, Caci E, Ferrera L, Pedemonte N, Barsanti C, Sondo E, Pfeffer U, Ravazzolo R, Zegarra-Moran O and Galietta LJ: TMEM16A, a membrane protein associated with calcium-dependent chloride channel activity. Science 322: 590-594, 2008.

77. Zimmermann H: Extracellular ATP and other nucleotides-ubiquitous triggers of intercellular messenger release. Purinergic Signal 12: 25-57, 2016.

78. Beech DJ: Inhibitory effects of histamine and bradykinin on calcium current in smooth muscle cells isolated from guinea-pig ileum. J Physiol 463: 565-583, 1993.

79. Morris AP, Scott JK, Ball JM, Zeng CQ, O'Neal WK and Estes MK: NSP4 elicits age-dependent diarrhea and $\mathrm{Ca}(2+)$ mediated I(-) influx into intestinal crypts of CF mice. Am J Physiol 277: G431-G444, 1999.

80. Yu K, Zhu J, Qu Z, Cui YY and Hartzell HC: Activation of the Ano1 (TMEM16A) chloride channel by calcium is not mediated by calmodulin. J Gen Physiol 143: 253-267, 2014.

81. Kunzelmann K, Ousingsawat J, Cabrita I, Doušová T, Bähr A, Janda M, Schreiber R and Benedetto R: TMEM16A in cystic fibrosis: Activating or inhibiting? Front Pharmacol 10: 3, 2019.

82.Zhang F, Wan H, Yang X, He J, Lu C, Yang S, Tuo B and Dong H: Molecular mechanisms of caffeine-mediated intestinal epithelial ion transports. Br J Pharmacol 176: 1700-1716, 2019.

83. Kunzelmann K and Mall M: Electrolyte transport in the mammalian colon: mechanisms and implications for disease Physiol Rev 82: 245-289, 2002.

84. Berg J, Yang H and Jan LY: Ca2+-activated Cl- channels at a glance. J Cell Sci 125: 1367-1371, 2012.

85. Zsembery A, Strazzabosco M and Graf J: Ca2+-activated Clchannels can substitute for CFTR in stimulation of pancreatic duct bicarbonate secretion. FASEB J 14: 2345-2356, 2000.

86. Berkes J, Viswanathan VK, Savkovic SD and Hecht G: Intestinal epithelial responses to enteric pathogens: Effects on the tight junction barrier, ion transport, and inflammation. Gut 52: 439-451, 2003

87. Flemström $\mathrm{G}$ and Isenberg JI: Gastroduodenal mucosal alkaline secretion and mucosal protection. News Physiol Sci 16: 23-28, 2001.

88. Simpson JE, Schweinfest CW, Shull GE, Gawenis LR, Walker NM, Boyle KT, Soleimani M and Clarke LL: PAT-1 (Slc26a6) is the predominant apical membrane $\mathrm{Cl}-\mathrm{HCO} 3-$ exchanger in the upper villous epithelium of the murine duodenum. Am J Physiol Gastrointest Liver Physiol 292: G1079-G1088, 2007.
89. Xiao F, Yu Q, Li J, Johansson ME, Singh AK, Xia W, Riederer B, Engelhardt R, Montrose M, Soleimani M, et al: Slc26a3 deficiency is associated with loss of colonic $\mathrm{HCO} 3(-)$ secretion, absence of a firm mucus layer and barrier impairment in mice. Acta Physiol (Oxf) 211: 161-175, 2014.

90. Vidyasagar S, Barmeyer C, Geibel J, Binder HJ and Rajendran VM: Role of short-chain fatty acids in colonic $\mathrm{HCO}(3)$ secretion. Am J Physiol Gastrointest Liver Physiol 288: G1217-G1226, 2005.

91. Vidyasagar S, Rajendran VM and Binder HJ: Three distinct mechanisms of HCO3- secretion in rat distal colon. Am J Physiol Cell Physiol 287: C612-C621, 2004.

92. Singh AK, Riederer B, Chen M, Xiao F, Krabbenhöft A, Engelhardt R, Nylander O, Soleimani M and Seidler U: The switch of intestinal Slc26 exchangers from anion absorptive to HCOFormula secretory mode is dependent on CFTR anion channel function. Am J Physiol Cell Physiol 298: C1057-C1065, 2010.

93. Singh AK, Liu Y, Riederer B, Engelhardt R, Thakur BK, Soleimani M and Seidler U: Molecular transport machinery involved in orchestrating luminal acid-induced duodenal bicarbonate secretion in vivo. J Physiol 591: 5377-5391, 2013.

94. Smith A, Contreras C, Ko KH, Chow J, Dong X, Tuo B, Zhang HH, Chen DB and Dong H: Gender-specific protection of estrogen against gastric acid-induced duodenal injury: Stimulation of duodenal mucosal bicarbonate secretion. Endocrinology 149: 4554-4566, 2008.

95. Lamprecht G, Hsieh CJ, Lissner S, Nold L, Heil A, Gaco V, Schäfer J, Turner JR and Gregor M: Intestinal anion exchanger down-regulated in adenoma (DRA) is inhibited by intracellular calcium. J Biol Chem 284: 19744-19753, 2009.

96. Feske S, Giltnane J, Dolmetsch R, Staudt LM and Rao A: Gene regulation mediated by calcium signals in T lymphocytes. Nat Immunol 2: 316-324, 2001

97. Rosenberg SS and Spitzer NC: Calcium signaling in neuronal development. Cold Spring Harb Perspect Biol 3: a004259, 2011

98. Stiber J, Hawkins A, Zhang ZS, Wang S, Burch J, Graham V, Ward CC, Seth M, Finch E, Malouf N, et al: STIM1 signalling controls store-operated calcium entry required for development and contractile function in skeletal muscle. Nat Cell Biol 10: 688-697, 2008.

99. Prakriya M and Lewis RS: Store-operated calcium channels. Physiol Rev 95: 1383-1436, 2015.

100. Baba Y, Hayashi K, Fujii Y, Mizushima A, Watarai H, Wakamori M, Numaga T, Mori Y, Iino M, Hikida M and Kurosaki T: Coupling of STIM1 to store-operated Ca2+ entry through its constitutive and inducible movement in the endoplasmic reticulum. Proc Natl Acad Sci USA 103: 16704-16709, 2006

101. Barr VA, Bernot KM, Srikanth S, Gwack Y, Balagopalan L, Regan CK, Helman DJ, Sommers CL, Oh-Hora M, Rao A and Samelson LE: Dynamic movement of the calcium sensor STIM1 and the calcium channel Orail in activated T-cells: Puncta and distal caps. Mol Biol Cell 19: 2802-2817, 2008.

102. Smyth JT, Lemonnier L, Vazquez G, Bird GS and Putney JW Jr: Dissociation of regulated trafficking of TRPC3 channels to the plasma membrane from their activation by phospholipase $\mathrm{C}$. J Biol Chem 281: 11712-11720, 2006.

103. Mercer JC, Dehaven WI, Smyth JT, Wedel B, Boyles RR, Bird GS and Putney JW Jr: Large store-operated calcium selective currents due to co-expression of Orai1 or Orai2 with the intracellular calcium sensor, Stim1. J Biol Chem 281: 24979-24990, 2006

104. Lefkimmiatis K, Moyer MP, Curci S and Hofer AM: 'cAMP sponge': A buffer for cyclic adenosine 3', 5'-monophosphate. PLoS One 4: e7649, 2009.

105. Rao JN, Rathor N, Zou T, Liu L, Xiao L, Yu TX, Cui YH and Wang JY: STIM1 translocation to the plasma membrane enhances intestinal epithelial restitution by inducing TRPC1-mediated $\mathrm{Ca}^{2+}$ signaling after wounding. Am J Physiol Cell Physiol 299: C579-C588, 2010

106. Onodera K, Pouokam E and Diener M: STIM1-regulated Ca2+ influx across the apical and the basolateral membrane in colonic epithelium. J Membr Biol 246: 271-285, 2013.

107. Smyth JT, DeHaven WI, Bird GS and Putney JW Jr: Role of the microtubule cytoskeleton in the function of the store-operated Ca2+ channel activator STIM1. J Cell Sci 120: 3762-3771, 2007.

108. Seo MD, Enomoto M, Ishiyama N, Stathopulos PB and Ikura M: Structural insights into endoplasmic reticulum stored calcium regulation by inositol 1,4,5-trisphosphate and ryanodine receptors. Biochim Biophys Acta 1853: 1980-1991, 2015. 
109. Putney JW Jr: Capacitative calcium entry revisited. Cell Calcium 11: 611-624, 1990.

110. Kocks S, Schultheiss G and Diener M: Ryanodine receptors and the mediation of $\mathrm{Ca} 2+-$ dependent anion secretion across rat colon. Pflugers Arch 445: 390-397, 2002.

111. Prole DL and Taylor CW: Inositol 1,4,5-trisphosphate receptors and their protein partners as signalling hubs. J Physiol 594: 2849-2866, 2016.

112. Lefkimmiatis K, Srikanthan M, Maiellaro I, Moyer MP, Curci S and Hofer AM: Store-operated cyclic AMP signalling mediated by STIM1. Nat Cell Biol 11: 433-442, 2009.

113. Nichols JM, Maiellaro I, Abi-Jaoude J, Curci S and Hofer AM 'Store-operated' cAMP signaling contributes to Ca2+-activated Cl- secretion in T84 colonic cells. Am J Physiol Gastrointest Liver Physiol 309: G670-G679, 2015.

114. Julio-Kalajzić F, Villanueva S, Burgos J, Ojeda M, Cid LP, Jentsch TJ and Sepúlveda FV: $K_{2 P}$ TASK-2 and KCNQ1-KCNE3 $\mathrm{K}^{+}$channels are major players contributing to intestinal anion and fluid secretion. J Physiol 596: 393-407, 2018.

115. Assaha DVM, Ueda A, Saneoka H, Al-Yahyai R and Yaish MW: The role of $\mathrm{Na}^{+}$and $\mathrm{K}^{+}$transporters in salt stress adaptation in glycophytes. Front Physiol 8: 509, 2017.

116. Wang J,Haanes KA and Novak I: Purinergic regulation of CFTR and $\mathrm{Ca}(2+)$-activated $\mathrm{Cl}(-)$ channels and $\mathrm{K}(+)$ channels in human pancreatic duct epithelium. Am J Physiol Cell Physiol 304 C673-C684, 2013.

117. Joiner WJ, Basavappa S, Vidyasagar S, Nehrke K, Krishnan S, Binder HJ, Boulpaep EL and Rajendran VM: Active K+ secretion through multiple $\mathrm{KCa}$-type channels and regulation by IKCa channels in rat proximal colon. Am J Physiol Gastrointest Liver Physiol 285: G185-G196, 2003.

118. Thompson-Vest N, Shimizu Y, Hunne B and Furness JB: The distribution of intermediate-conductance, calcium-activated, potassium (IK) channels in epithelial cells. J Anat 208: 219-229, 2006.

119. McNamara B, Winter DC, Cuffe JE, O'Sullivan GC and Harvey BJ: Basolateral $\mathrm{K}+$ channel involvement in forskolin-activated chloride secretion in human colon. J Physiol 519: 251-260, 1999.

120. Du C, Chen S, Wan H, Chen L, Li L, Guo H, Tuo B and Dong H: Different functional roles for $\mathrm{K}^{+}$channel subtypes in regulating small intestinal glucose and ion transport. Biol Open 8: bio042200, 2019.

121. Dong H, Smith A, Hovaida M and Chow JY: Role of $\mathrm{Ca} 2+$-activated $\mathrm{K}+$ channels in duodenal mucosal ion transport and bicarbonate secretion. Am J Physiol Gastrointest Liver Physiol 291: G1120-G1128, 2006.

122. Ottolia M and Philipson KD: NCX1: Mechanism of transport. Adv Exp Med Biol 961: 49-54, 2013.

123. Brini $\mathrm{M}$ and Carafoli E: The plasma membrane Ca2+ ATPase and the plasma membrane sodium calcium exchanger cooperate in the regulation of cell calcium. Cold Spring Harb Perspect Biol 3: a004168, 2011.

124. Lee SY and Kim JH: Mechanisms underlying presynaptic $\mathrm{Ca} 2+$ transient and vesicular glutamate release at a CNS nerve terminal during in vitro ischaemia. J Physiol 593: 2793-2806, 2015

125. Liao QS, Du Q, Lou J, Xu JY and Xie R: Roles of $\mathrm{Na}^{+} / \mathrm{Ca}^{2+}$ exchanger 1 in digestive system physiology and pathophysiology. World J Gastroenterol 25: 287-299, 2019.

126. Seip G, Schultheiss G, Kocks SL and Diener M: Interaction between store-operated non-selective cation channels and the $\mathrm{Na}(+)-\mathrm{Ca}(2+)$ exchanger during secretion in the rat colon. Exp Physiol 86: 461-468, 2001

127. Dong H, Sellers ZM, Smith A, Chow JY and Barrett KE: $\mathrm{Na}(+) / \mathrm{Ca}(2+)$ exchange regulates $\mathrm{Ca}(2+)$-dependent duodenal mucosal ion transport and $\mathrm{HCO}(3)(-)$ secretion in mice. Am J Physiol Gastrointest Liver Physiol 288: G457-G465, 2005.

128. Narayanan M, Reddy KM and Marsicano E: Peptic ulcer disease and Helicobacter pylori infection. Mo Med 115: 219-224, 2018

129. Iijima K, Kanno $T$, Koike $T$ and Shimosegawa $T$ : Helicobacter pylori-negative, non-steroidal anti-inflammatory drug: Negative idiopathic ulcers in Asia. World J Gastroenterol 20: 706-713, 2014.

130. Goderska K, Agudo Pena S and Alarcon T: Helicobacter pylori treatment: Antibiotics or probiotics. Appl Microbiol Biotechnol 102: 1-7, 2018.
131. Phan J, Benhammou JN and Pisegna JR: Gastric hypersecretory states: Investigation and management. Curr Treat Options Gastroenterol 13: 386-397, 2015.

132. Mejia A and Kraft WK: Acid peptic diseases: Pharmacological approach to treatment. Expert Rev Clin Pharmacol 2: 295-314, 2009.

133. Garcia MA, Yang N and Quinton PM: Normal mouse intestinal mucus release requires cystic fibrosis transmembrane regulator-dependent bicarbonate secretion. J Clin Invest 119: 2613-2622, 2009.

134. Allen A and Flemström G: Gastroduodenal mucus bicarbonate barrier: Protection against acid and pepsin. Am J Physiol Cell Physiol 288: C1-C19, 2005.

135. Barkas F, Liberopoulos E, Kei A and Elisaf M: Electrolyte and acid-base disorders in inflammatory bowel disease. Ann Gastroenterol 26: 23-28, 2013.

136. Hwang SJ, Basma N, Sanders KM and Ward SM: Effects of new-generation inhibitors of the calcium-activated chloride channel anoctamin 1 on slow waves in the gastrointestinal tract. Br J Pharmacol 173: 1339-1349, 2016

137. Findling R, Frishman W, Javed MT, Heffer S and Brandt L: Calcium channel blockers and the gastrointestinal tract. Am J Ther 3: 383-408, 1996.

138. Zhang YZand Li YY: Inflammatory bowel disease: Pathogenesis. World J Gastroenterol 20: 91-99, 2014.

139. Tanoue T, Umesaki Y and Honda K: Immune responses to gut microbiota-commensals and pathogens. Gut Microbes 1: 224-233, 2010.

140. Ghishan FK and Kiela PR: Epithelial transport in inflammatory bowel diseases. Inflamm Bowel Dis 20: 1099-1109, 2014

141. Lau KS, Nakashima O, Aalund GR, Hogarth L, Ujiie K, Yuen J and Star RA: TNF-alpha and IFN-gamma induce expression of nitric oxide synthase in cultured rat medullary interstitial cells. Am J Physiol 269: F212-F217, 1995.

142. Das S, Jayaratne R and Barrett KE: The role of ion transporters in the pathophysiology of infectious diarrhea. Cell Mol Gastroenterol Hepatol 6: 33-45, 2018.

143. Manoharan P, Coon S, Baseler W, Sundaram S, Kekuda R and Sundaram U: Prostaglandins, not the leukotrienes, regulate $\mathrm{Cl}(-) / \mathrm{HCO}(3)(-)$ exchange (DRA, SLC26A3) in villus cells in the chronically inflamed rabbit ileum. Biochim Biophys Acta 1828: 179-186, 2013

144. Yang D, Shcheynikov N, Zeng W, Ohana E, So I, Ando H, Mizutani A, Mikoshiba K and Muallem S: IRBIT coordinates epithelial fluid and $\mathrm{HCO} 3$ - secretion by stimulating the transporters $\mathrm{pNBC} 1$ and CFTR in the murine pancreatic duct. J Clin Invest 119: 193-202, 2009.

145. Lohi H, Kujala M, Kerkelä E, Saarialho-Kere U, Kestilä M and Kere J: Mapping of five new putative anion transporter genes in human and characterization of SLC26A6, a candidate gene for pancreatic anion exchanger. Genomics 70: 102-112, 2000.

146. Anbazhagan AN, Priyamvada S, Alrefai WA and Dudeja PK: Pathophysiology of IBD associated diarrhea. Tissue Barriers 6 : e1463897, 2018.

147. Priyamvada S, Gomes R, Gill RK, Saksena S, Alrefai WA and Dudeja PK: Mechanisms underlying dysregulation of electrolyte absorption in inflammatory bowel disease-associated diarrhea. Inflamm Bowel Dis 21: 2926-2935, 2015.

148. Priyamvada S, Anbazhagan AN, Gujral T, Borthakur A, SaksenaS, Gill RK, Alrefai WA and Dudeja PK: All-trans-retinoic acid increases SLC26A3 DRA (Down-regulated in Adenoma) expression in intestinal epithelial cells via HNF-1 $\beta$. J Biol Chem 290: 15066-15077, 2015.

149. Seidler U and Nikolovska K: Slc26 Family of anion transporters in the gastrointestinal tract: Expression, function, regulation, and role in disease. Compr Physiol 9: 839-872, 2019.

This work is licensed under a Creative Commons Attribution-NonCommercial-NoDerivatives 4.0 International (CC BY-NC-ND 4.0) License. 